Review

\title{
Low-Voltage Ride-Through Techniques in DFIG-Based Wind Turbines: A Review
}

\author{
Boyu Qin ${ }^{1, *}{ }^{\mathbb{D}}$, Hengyi $\mathrm{Li}^{1}{ }^{1}$, Xingyue $\mathrm{Zhou}^{1}{ }^{1}, \mathrm{Jing} \mathrm{Li}^{2}$ and Wansong Liu ${ }^{1}$ \\ 1 State Key Laboratory of Electrical Insulation and Power Equipment, and the school of Electrical Engineering, \\ Xi'an Jiaotong University, Xi'an 710049, Shaanxi Province, China; 1619503880@stu.xjtu.edu.cn (H.L.); \\ zxy10158542@stu.xjtu.edu.cn (X.Z.); jerry1996@stu.xjtu.edu.cn (W.L.) \\ 2 Jiangsu Nuclear Power Co., Ltd., Lianyungang 222000, Jiangsu Province, China; lijing10@cnnp.com.cn \\ * Correspondence: qinboyu@xjtu.edu.cn; Tel.: +86-136-5925-0017
}

Received: 15 February 2020; Accepted: 15 March 2020; Published: 22 March 2020

check for updates

\begin{abstract}
In recent years, considerable advances were made in wind power generation. The growing penetration of wind power makes it necessary for wind turbines to maintain continuous operation during voltage dips, which is stated as the low-voltage ride-through (LVRT) capability. Doubly fed induction generator (DFIG)-based wind turbines (DFIG-WTs), which are widely used in wind power generation, are sensitive to disturbances from the power grid. Therefore, several kinds of protection circuits and control methods are applied to DFIG-WTs for LVRT capability enhancement. This paper gives a comprehensive review and evaluation of the proposed LVRT solutions used in DFIG-WTs, including external retrofit methods and internal control techniques. In addition, future trends of LVRT solutions are also discussed in this paper.
\end{abstract}

Keywords: Doubly fed induction generator; low-voltage ride through; wind turbine; rotor-side converter; grid-side converter

\section{Introduction}

In recent years, renewable energy generation made great progress worldwide to meet the challenge of drastic climate changes and increasing energy demands [1]. Among various renewable energy sources, wind energy is the most rapidly growing one around the world [2,3]. In 2018, the $51.3 \mathrm{GW}$ of new installations brought total cumulative installations of wind power up to $591 \mathrm{GW}$, and the Global Wind Energy Council (GWEC) expects that more than 55 GW of new capacity will be added each year until 2023. In 2019, with the $25.7 \mathrm{GW}$ of new wind power installations, the cumulative wind power installations of China increased by $14 \%$ to $210 \mathrm{GW}$. With the development of wind energy, wind turbines (WTs) are more widely used in electrical power systems.

WTs can be classified into four basic categories based on the ways of speed control: fixed-speed wind turbines, limited variable-speed-controlled wind turbines, doubly fed induction generator (DFIG)-based wind turbines (DFIG-WTs), and full variable-speed-controlled wind turbines $[4,5]$. Among these four types of wind turbines, DFIG-WTs are mostly preferred in practical applications due to their advantages including simple installation, low cost, variable-speed constant frequency, and independent control of active and reactive power [6]. Figure 1 shows the schematic diagram of a DFIG. The stator is connected to the power grid directly, and the rotor is linked to the power grid through a back-to-back voltage source converter, which comprises a rotor-side converter (RSC) and a grid-side converter (GSC). RSC is used to control the active power and reactive power delivered and to achieve the maximum power capture. GSC is used to control the active power and reactive power delivered, as well as maintain the direct current (DC)-link voltage [1,7]. 


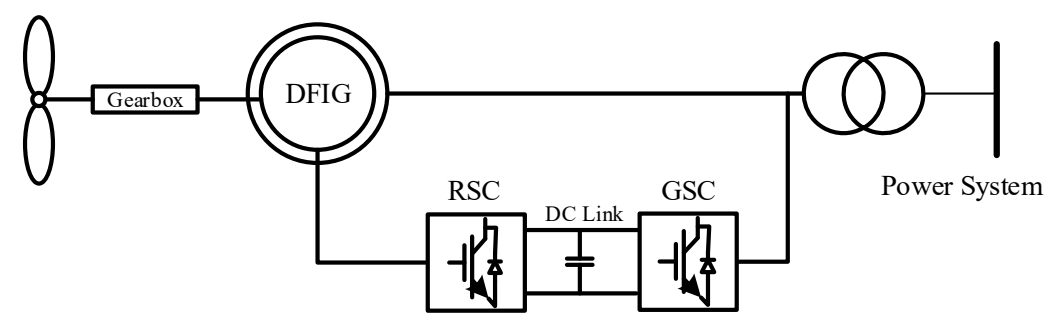

Figure 1. Basic structure of doubly fed induction generator (DFIG).

DFIG-WTs are susceptible to grid voltage dips and disturbances. During grid voltage dips, the stator and GSC are influenced directly by the sudden change in DFIG bus voltage. Stator perturbations will induce large voltages in rotor windings and lead to uncontrolled rotor current. The rotor overcurrent may cause a large increase in DC-link voltage. Both rotor inrush current and DC-link overvoltage can damage wind turbines [8] and may lead to tripping of DFIG-WTs. The ability to ensure continuous operation during voltage dips, as well as minimize re-synchronization problems after the clearance of faults, is stated as low-voltage ride-through (LVRT) capability.

In the past, the penetration level of wind energy was extremely small compared with conventional generation systems [9]. Therefore, wind turbines were allowed to disconnect from the power grid during voltage dips to avoid overcurrent. However, with the penetration of wind energy in electrical power systems increasing, a sudden loss of wind power during voltage dips can result in control problems of system frequency and voltage, which leads to a system collapse in the worst case $[10,11]$. Hence, it is ideal to make wind turbines stay connected to the power grid and provide support during transient periods. Therefore, the LVRT capability in wind turbines is now mandatory. With emphasis on the LVRT capability of DFIG-WTs, many countries updated their grid code requirements (GCRs). The German LVRT grid criteria are mostly preferred over other GCRs in practical applications [1]; they require that (1) wind turbines shall remain connected to grid for at least $0.65 \mathrm{~s}$ after fault inception, (2) the permitted fault voltage is $15 \%$ of its rated voltage, and (3) the voltage should recover to $90 \%$ of its rated voltage within $3 \mathrm{~s}$ after the clearance of faults. According to the GCR for LVRT, wind turbines should have the ability to ensure continuous operation during voltage dips, and the voltage should be kept above the curve shown in Figure 2. In addition, most GCRs require reactive current injection during voltage dips. The E.ON requirement for voltage support proposes that wind turbines should provide reactive current when the voltage reaches the dead band limit, and larger reactive current injection is needed when the voltage dips go deeper, as presented in Figure 3. The reactive current support in response to severe voltage dips must be achieved within $20 \mathrm{~ms}$ of fault detection [12].

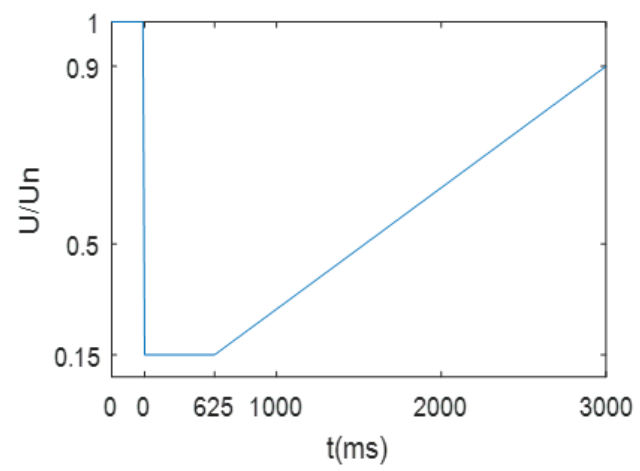

Figure 2. Wind turbine German low-voltage ride-through (LVRT) grid criteria for voltage dips. 


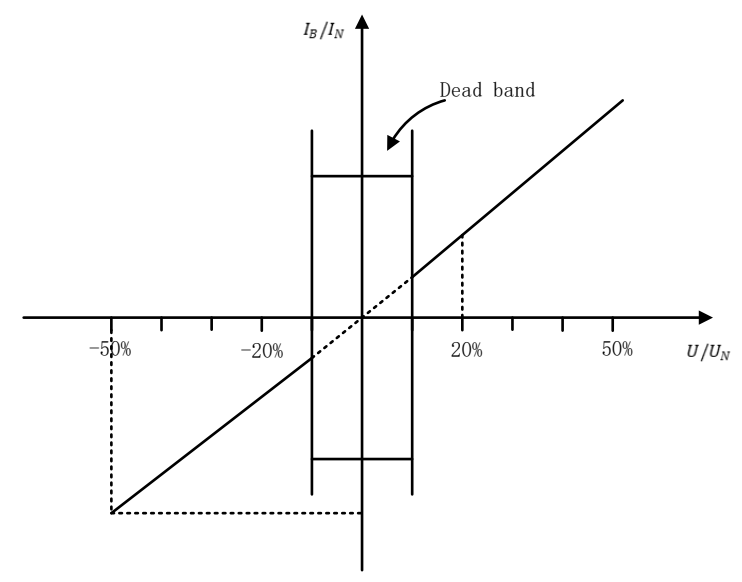

Figure 3. Reactive power requirement as per E.ON grid code.

To meet the demands of GCRs, the behavior of the DFIG during and after voltage dips should be controlled as follows: (1) overcurrent and overvoltage in stator and rotor windings should be restrained to avoid damaging the power converters; (2) speed of turbines and electromagnetic torques should be properly designed to guarantee safe operation [13]; (3) DC-link voltage should be kept constant to ensure the desirable operation of RSC and GSC [14]; (4) enough reactive power is needed to promote grid recovery [15]. To solve these problems, various methods including external retrofit techniques and internal control techniques were proposed to ameliorate the LVRT capability of DFIG-WTs.

The review of LVRT techniques can serve as a reference to analyze the existing control methods and identify the prospects for further improvements in this area. In Reference [9], a comprehensive review about the grid code regulations enforced on large wind power plants was presented. However, the specific LVRT techniques which fulfill various grid code requirements were not covered in this paper. A technical review of LVRT techniques applied in DFIG-WTs was discussed in Reference [4], while a significant portion was dedicated to LVRT protection circuits and hybrid combinations. In Reference [16], relevant literature about LVRT strategies was studied regarding when DFIG-WTs are connected to an alternating current (AC) network or voltage source converter (VSC) based high voltage direct current (HVDC). However, this paper mainly focused on the power surplus of two-terminal systems and DC voltage control of multi-terminal systems. A review on LVRT techniques for improving the transient stability of DFIG-WTs was proposed in Reference [1], where LVRT solutions were divided into protection circuits, Flexible Alternating Current Transmission System (FACTS) device-based methods, traditional control methods, and advanced control techniques. However, the lack of comparative analysis results may restrict its application value.

This paper gives a comprehensive review and evaluation of the proposed LVRT techniques used in DFIG-WTs to analyze the current level of LVRT techniques. The main contributions of this paper are summarized as follows: firstly, this paper offers a remarkably up-to-date review of the state of LVRT techniques applied in DFIG-WTs, especially the latest achievements in this area. Secondly, novel classifications are proposed in this paper based on internal/external retrofits and the location of modifications. The analysis results and discussions show the potential of LVRT techniques and provide future research directions based on this work.

This paper is organized as follows: Section 2 presents the classification of LVRT techniques. Section 3 gives an introduction of rotor-side external retrofit techniques. Stator-side external retrofit techniques are described in Section 4. Section 5 introduces internal control techniques. Section 6 concludes this paper and discusses future research trends.

\section{Classification of LVRT Techniques}

External retrofit techniques can effectively solve these problems and enhance the LVRT capability by installing devices to DFIG-WTs. Different device topologies and installed locations determine the 
way external retrofit techniques work. For example, the rotor-side crowbar circuit is used to restrain rotor current increase and protect the RSC [17], while a DC-chopper can limit the overcharge during grid voltage dips [18]. According to the above factors, external retrofit techniques are classified into two parts: rotor-side external retrofit techniques and stator-side external retrofit techniques. Internal control techniques are prioritized choices for new installations of wind turbines [19]. Through properly designed control strategies, internal control techniques make full use of the DFIG's own capability to enhance the LVRT capability of DFIG-WTs. Thus, they are more economical by avoiding extra hardware devices. Many advanced control techniques are proposed to provide better dynamic performances and enhance the LVRT capability of DFIG-WTs.

\section{Rotor-Side External Retrofit Techniques}

Due to the coupling between stator and rotor, grid voltage dips may result in rotor overcurrent and overvoltage. Crowbars, DC-choppers, series dynamic resistors (SDRs), and DC-link energy storage systems (ESSs) can be installed on the rotor side to restrain the inrush current and the increasing voltage. These extra device installations are classified as rotor-side external retrofit techniques.

\subsection{Crowbar Method}

The crowbar is the most prevalent LVRT protection circuit adopted in DFIG-WTs. A crowbar circuit comprises a set of paralleled resistors installed between rotor windings and the AC-side of the RSC [18,20], as shown in Figure 4. When rotor overcurrent or DC-link overvoltage occurs, the crowbar is triggered and a low-resistance path is created to allow high currents to flow through. In this operation mode, the RSC is disconnected from rotor windings via the closed crowbar switch [21] and the damage of overcurrent can be avoided. With the crowbar circuit triggered, the DFIG-WT is transformed into a standard induction motor and the excitation control is lost. In this case, the DFIG consumes a large amount of reactive power from the power grid via stator windings, which may deteriorate the terminal voltage dynamics. In general, removing the crowbar in a timely manner can make the RSC provide reactive power to the grid as soon as possible to accelerate the grid voltage recovery. However, more crowbar connection time is needed to ensure that the natural flux is damped up to a desirable level so that the RSC can recover the DFIG control [22]. Therefore, the crowbar connection time should be chosen carefully to improve the transient stability of DFIG-WTs. Another important factor which influences the crowbar performance is the crowbar resistance. On one hand, low crowbar resistance can lead to serious rotor overcurrent and electromagnetic torque with a large peak [22]. On the other hand, increased crowbar resistance can lead to rotor overvoltage and DC-link overvoltage, which may cause damage to rotor windings. Thus, an appropriate value of the crowbar resistance should be selected to meet the aforementioned issues.

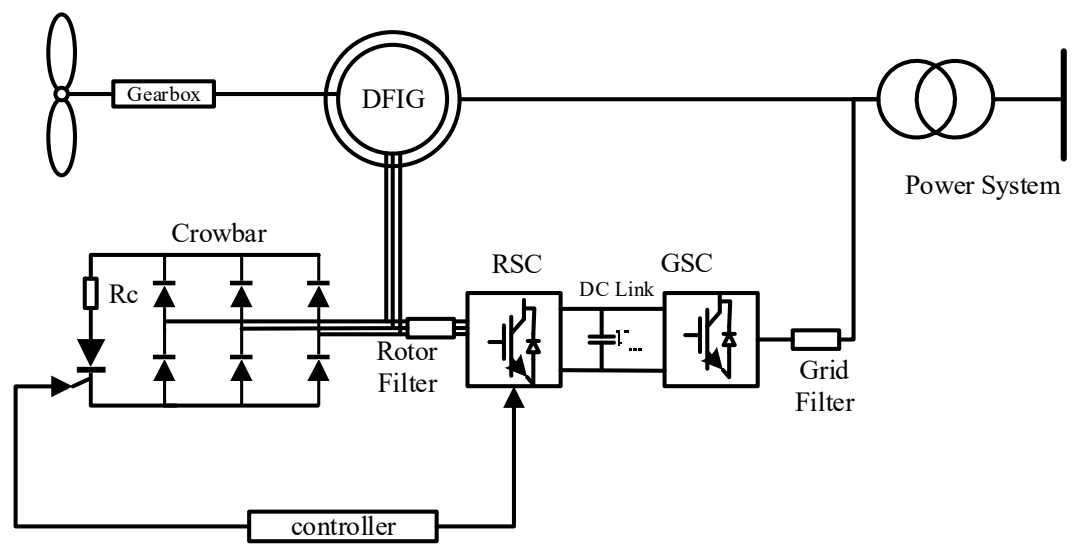

Figure 4. Crowbar protection circuit. 
To improve the control effect based on these important factors, many crowbar modifications were proposed in terms of both configuration and strategy. An analytical expression for crowbar resistance was derived in Reference [23]. By taking grid impedance into consideration, the appropriate crowbar resistance can be calculated, which shows desirable performance in practical applications. Crowbar resistance chosen via the traditional method is close to the margin of LVRT security region. The parallel R-L configuration crowbar with series R-L circuit, as shown in Figure 5, was proposed in Reference [20]. During the transient period, the parallel R-L configuration crowbar is activated and maintains a connection to the terminal of rotor windings and the RSC. The smooth transition can be guaranteed through the injection of the proposed circuit.

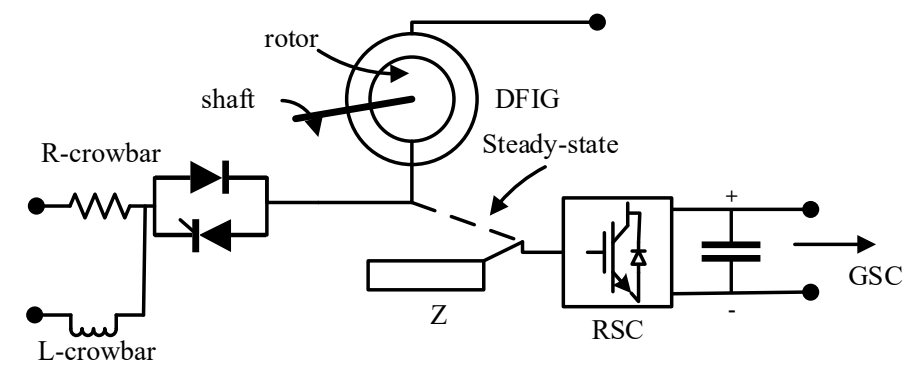

Figure 5. Parallel R-L configuration crowbar.

\subsection{Chopper}

A DC-chopper is a resistance circuit connected in parallel with a DC-link capacitor between the RSC and GSC, as shown in Figure 6. A braking resistor is used to maintain DC-link voltage by accepting transient rotor overcurrent [24]. The insulated gate bipolar transistor (IGBT), in series with resistors, controls the inserting and quitting time of the DC chopper circuit. Whenever grid faults occur, the rapid increase in rotor current will lead to DC-link overvoltage by charging the DC-link capacitor. When DC-link voltage exceeds the threshold value, the IGBT should be closed to short the link with braking resistors $[25,26]$. As a result, DC-link voltage can be adjusted to an acceptable level. However, the rotor transient overcurrent and DC-link overcurrent cannot be restrained by a conventional DC-chopper. In this situation, the RSC switching is stopped. A modified DC-chopper was proposed not only to restrain DC-link voltage on a desirable level, but also restrict the overcurrent on both the rotor side and the stator side in Reference [27]. The modified DC-chopper is placed between the DC-link capacitor and RSC, and DC chopper resistance can be inserted through three extra semiconductors. By employing the modified DC chopper, rotor current and stator current, as well as DC-link voltage, can be controlled without utilizing the extra fault-current-limit method and voltage sag compensation approach [27].

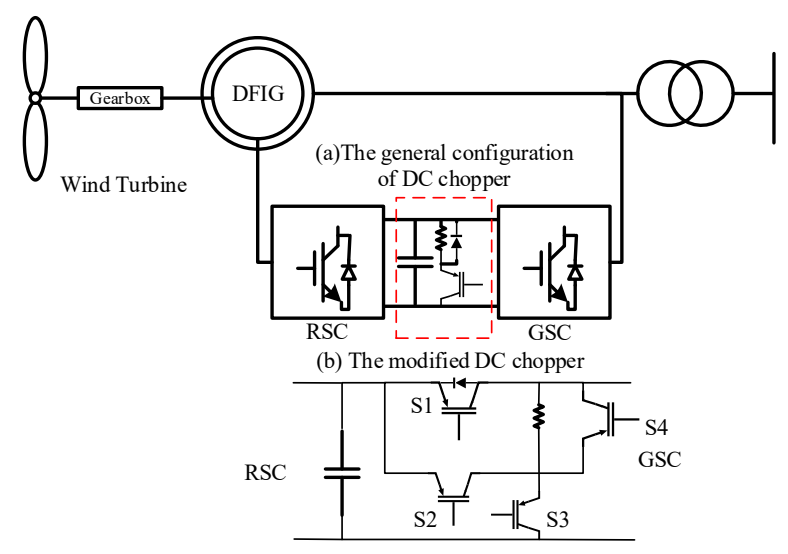

Figure 6. Direct current (DC) chopper protection circuit. 


\subsection{Series Dynamic Resistor}

The SDR is a configuration where a dynamic resistor is put in series between rotor windings and the RSC to limit rotor overcurrent during grid voltage dips, as shown in Figure 7. The operation of the SDR is controlled by a power electronic switch: (1) in steady-state conditions, the switch is closed and the series resistor is bypassed; (2) during fault conditions, the switch turns open and a series resistor is connected between the RSC and rotor windings, where rotor current flows through the resistor [28]. Due to the specific topology, the SDR can directly control the magnitude of current. Furthermore, the limitation of rotor current can reduce the charging current to a DC-link capacitor; thus, DC-link overvoltage can be avoided [29,30]. During voltage dips, the high rotor voltage is shared by the series resistor, and the continuous operation of converter can be guaranteed. By maximizing the operation time of the RSC, more reactive power can be generated from DFIG-WTs to support the terminal voltage.

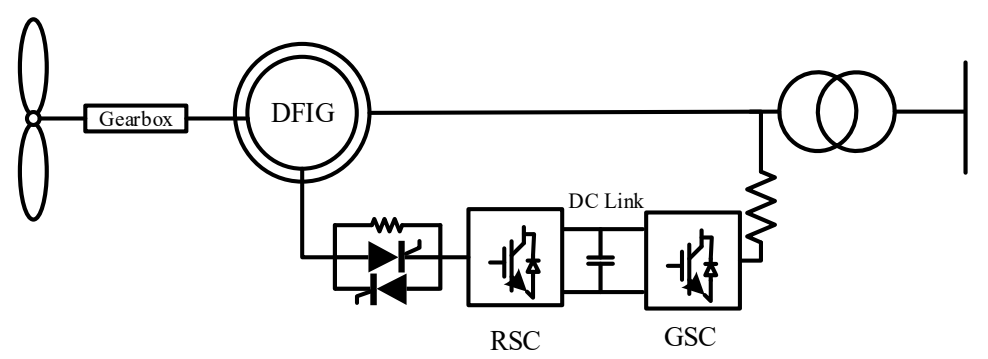

Figure 7. Series dynamic resistance (SDR) protection circuit.

A coordinated control approach which consists of a series rotor-side crowbar (SRSC), DC-link capacitor crowbar (DCCC), and circuit breaking (CB) was proposed in Reference [31]. In this scheme, the SRSC is in parallel with CB, and it connects in series with rotor windings and the RSC. The DCCC is connected in parallel with the DC-link capacitor with the function of restricting DC-link overvoltage. Figure 8 shows the configuration of the coordinated control approach. In steady-state conditions, the rotor is connected with the RSC through CB, and the normal operation of the generator can be ensured. During grid voltage dips, the SRSC and DCCC operate in coordination to protect the RSC and DC-link capacitor. Furthermore, the RSC can be connected with rotor windings through the SRSC and maintain operation to provide control efforts.

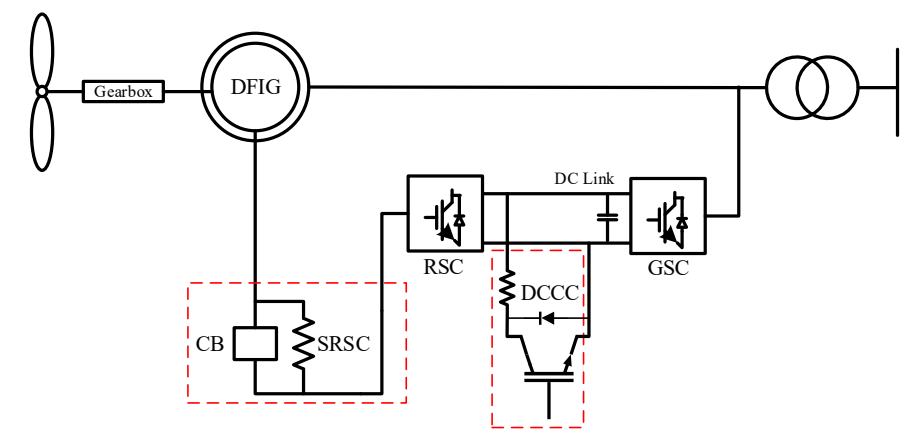

Figure 8. Coordinated control of a series rotor-side crowbar (SRSC) and DC-link capacitor crowbar (DCCC).

\subsection{DC-Link Energy Storage System}

The ESS acts as a buffer in DFIG-WTs with the function of keeping the DC-link power flow through charging/discharging [32]. Typical DC-link ESS configurations include indirect DC-link ESSs and direct DC-link ESSs. Figure 9 shows the topology of an indirect DC-link ESS, which comprises a battery and a buck-boost converter acting as a DC/DC converter. The battery is connected in paralleled with the DC-link, and the energy storage system is able to share the DC-link with the GSC when it is 
activated [33]. By applying an indirect ESS to the DC-link, DFIG-WTs have better capability to control DC-link voltage and balance the power flow in the system [34]. Due to the specific structure, the ESS can smooth the steady-state active power output. During transient periods, the ESS can endow the RSC with the ability to provide enough reactive power support via additional demagnetizing current injection. Thus, the terminal voltage dynamics can be improved. To reduce costs and increase efficiency by avoiding converter losses, a direct DC-link ESS configuration was proposed in Reference [35]. In this topology, the energy storage is connected in parallel with the DC-link without any extra converter. Moreover, the direct DC-link ESS also shows the desirable capability to smooth output power during voltage dips. However, the demagnetizing current which is injected from converters into the rotor circuit may result in rotor overcurrent.

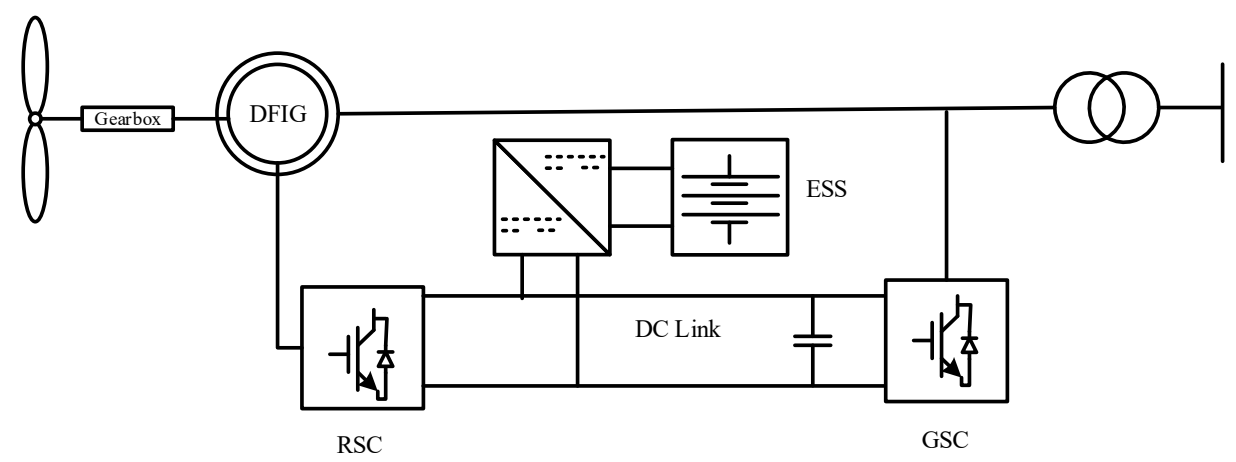

Figure 9. Indirect DC-link energy storage system (ESS).

An advanced auxiliary ESS control system was proposed in Reference [36], and the auxiliary control configuration is shown in Figure 10. The operation of the ESS is controlled by power electronic switches. During normal operation, power electronic switches SW1 and SW2 are off and the control system is disabled. When disturbances occur in the output power, the primary control system can participate in smoothing the output power by switching SW1 off and SW2 on. During the fault condition, the auxiliary control system is activated by switching SW1 on and SW2 off to restrict DC link overvoltage. This auxiliary ESS control system provides different functions based on different conditions. Therefore, both steady-state and transient stability can be enhanced by applying this control system.

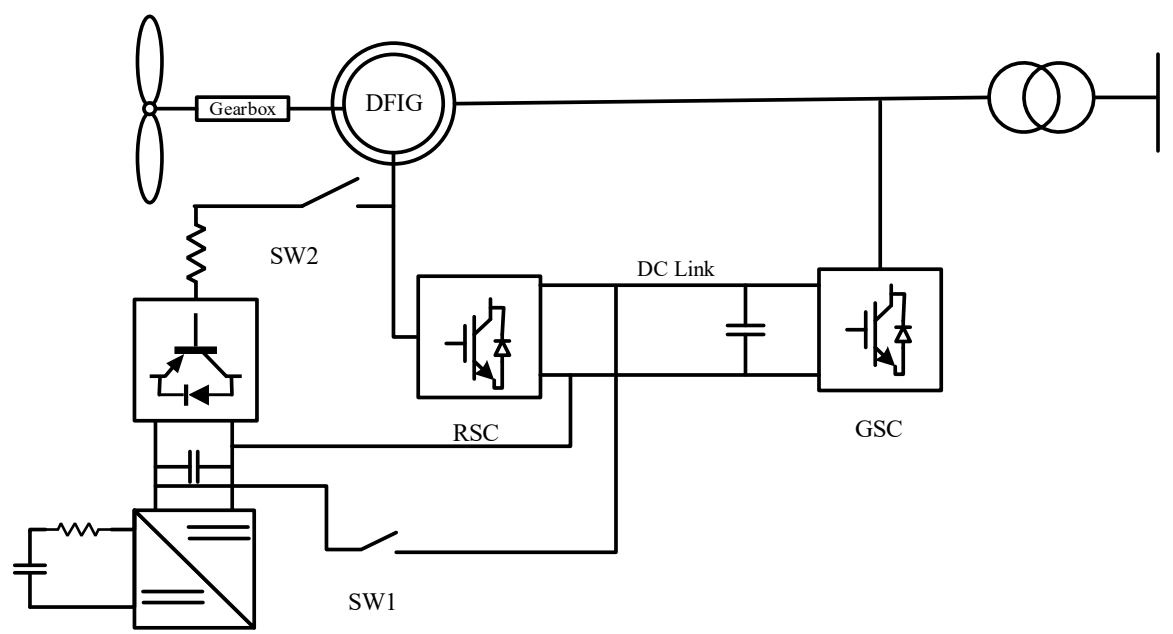

Figure 10. Auxiliary control system of ESS. 
In the DC-link ESS, super-capacitors can replace traditional energy storages due to the function of matching the intermittent wind energy. Super-capacitors do not have an electrochemical reaction but have electric charge absorption and desorption during charging and discharging periods [37]. Super-capacitors can be connected with the DC-link capacitor directly or via an interface. By implementing a super-capacitor to the DC-link, the oscillation of stator current, stator voltage, and DC-link voltage can be significantly restrained [38]. Although the super-capacitor imposes a higher cost, it can enhance the transient stability of the DFIG, and the operation of the machine does not need to be modified [39].

\subsection{Comparative Results Analysis of Rotor-Side External Retrofit Techniques}

Rotor-side external retrofit techniques have a desirable control effect in restraining rotor overcurrent, controlling DC-link voltage, and improving terminal voltage dynamics. To compare the control effect of various rotor-side external retrofit techniques, a single-machine infinite bus (SMIB) system was established, as depicted in Figure 11. The rated active power of the wind farm was 9 MW with six 1.5 MW DFIG-WTs, and the detailed models of DFIG-WTs were provided by Matlab/Simulink R2016a. The wind speed in the wind farm was maintained as a constant of $15 \mathrm{~m} / \mathrm{s}$. A three-phase to ground fault with grounding resistance of $0.5 \Omega$ occurs at the end of $25 \mathrm{kV}$ feeder at $0 \mathrm{~s}$, and the fault is cleared at $0.1 \mathrm{~s}$. According to the GCR for LVRT, the maximum limit of rotor current was set as 2 p.u. Typical models of an active crowbar [20], SDR [30], ESS [36], and DC chopper [25] were implemented in MATLAB/Simulink for simulation. The durations of the active crowbar circuit and SDR were set as $0.02 \mathrm{~s}$, while the ESS and DC-chopper remained activated during grid fault. The comparative results are shown in Figure 12.

Figure 12a shows the control effect in restricting rotor current. Since the ESS and a conventional DC chopper may result in rotor overcurrent, they are not included. As shown in Figure 12a, the active crowbar circuit shows better performance in restricting rotor overcurrent compared with the SDR, because it creates a low-resistance path to allow high-current flow through during transient periods. The desirable control effect in restricting rotor current endows the active crowbar circuit with the ability to avoid overcharging in DC capacitors, such that the active crowbar circuit can restrain DC-link overvoltage better than the SDR, as shown in Figure 12b. The DC-chopper can maintain DC-link voltage in an acceptable range by quickly discharging the excess active power in the DC-link. Figure $12 \mathrm{c}$ shows the comparative results of transient reactive power support. Since the SDR maximizes the operation time of the RSC, more reactive power is generated when the SDR is applied compared with the active crowbar circuit. The ESS offers more transient reactive power support during transient periods, which results in better terminal voltage dynamics, as shown in Figure 12d. Since the reactive power generation mainly depends on RSC control, the active crowbar circuit and SDR provide a similar control effect for supporting terminal voltage. The DC-chopper has no control effect on reactive power support and voltage dynamics improvement; thus, it is not presented in Figure 12c,d.

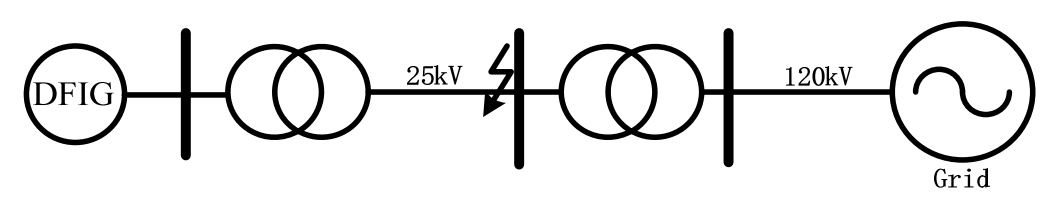

Figure 11. The structure of single-machine infinite bus (SMIB) system. 


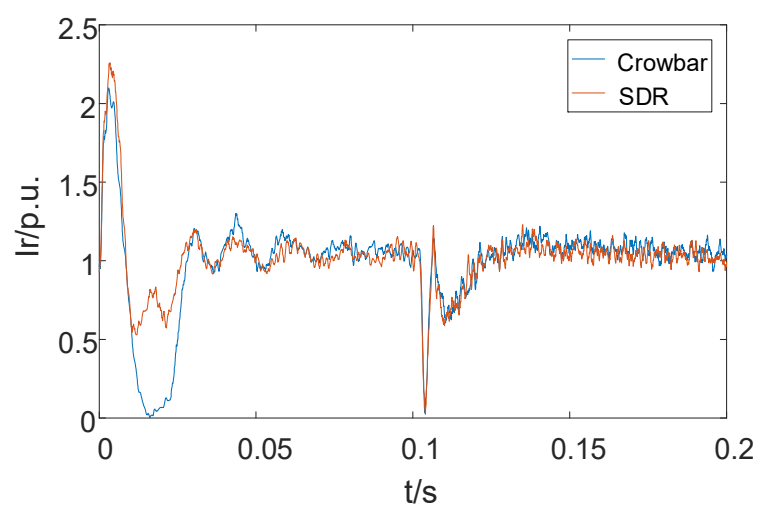

(a)

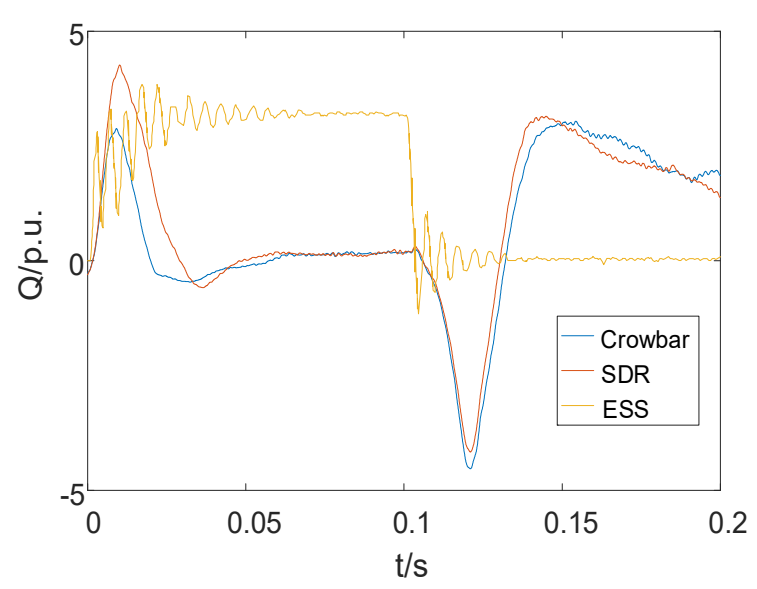

(c)

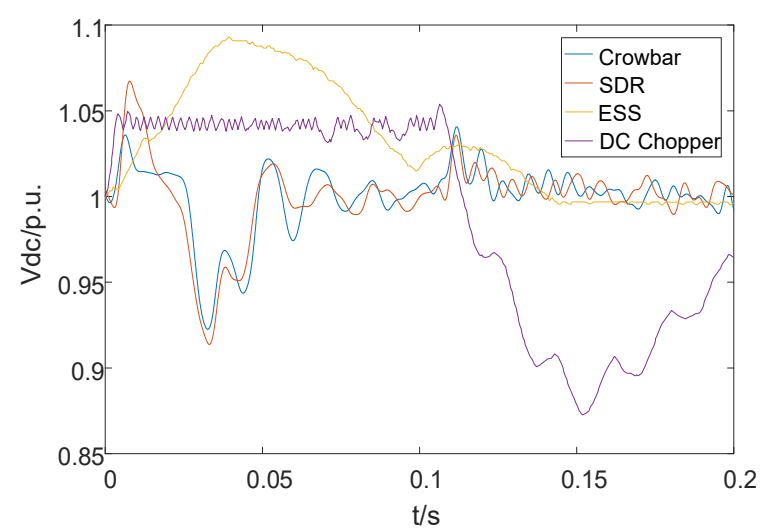

(b)

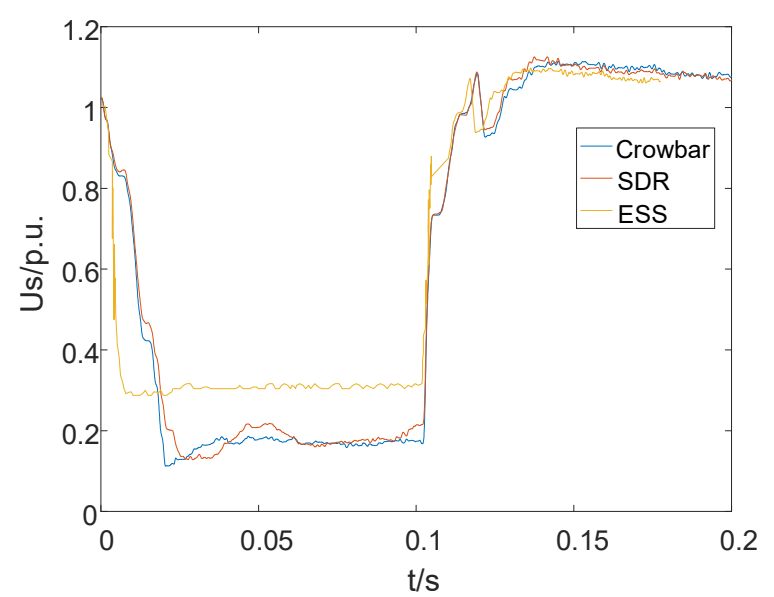

(d)

Figure 12. Control effect comparison of rotor-side external retrofit techniques in (a) rotor current, (b) DC-link voltage, (c) reactive power support, and (d) terminal voltage.

\section{Stator-Side External Retrofit Techniques}

Due to the direct connection between the stator and power grid, grid voltage dips can lead to stator overcurrent and voltage sags at the terminal. Series dynamic braking resistors (SDBRs), reactive power compensation devices, fault current limiter (FCLs), and series grid-side converter (SGSCs) can be installed on the stator side of DFIGs with the function of keeping stator current and stator voltage on a desirable level. These external devices are classified as stator-side external retrofit techniques.

\subsection{Series Dynamic Braking Resistor}

The SDBR comprises a resistor and a paralleled IGBT circuit. Generally, the SDBR is applied in series with line to restrain current during disturbances [40]. In a DFIG, the SDBR is installed between the stator and the power grid, as shown in Figure 13. By dynamically inserting a resistor in the stator, the SDBR can increase the terminal voltage during grid voltage dips. In addition, the destabilizing depression of electrical torque and power can be restricted [41]. However, when a traditional SDBR is activated, the back-to-back converter has to be disabled due to the hardship in synchronizing stator voltage, and the variable frequency switching scheme may result in undesirable voltage quality [42]. To solve these problems, a modulated series dynamic braking resistor (MSDBR) was proposed, which comprises a high-power braking resistor and two parallel IGBTs for each phase [43]. The MSDBR is also connected in series with the stator and grid, and this device is controlled by the fixed frequency 
Pulse-Width Modulation (PWM) signals to dissipate excessive power and maintain the terminal voltage magnitude in a desirable range.

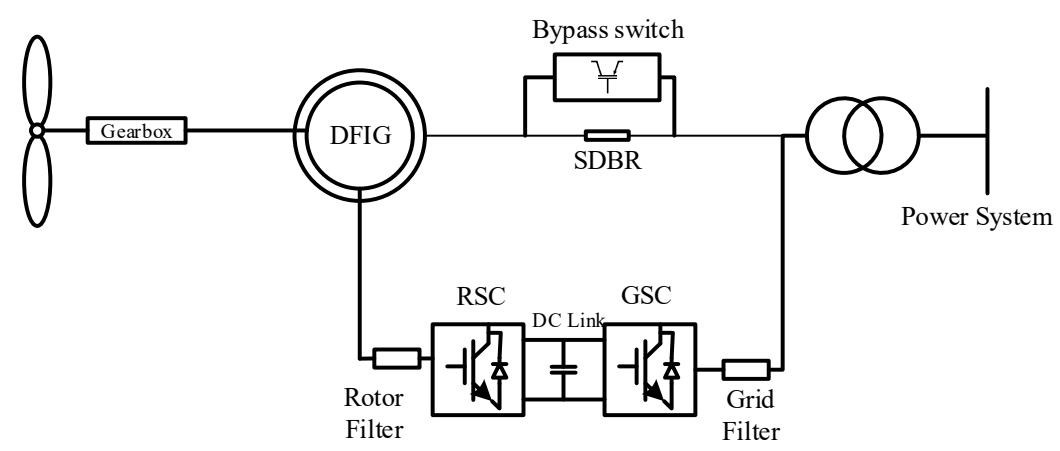

Figure 13. Series dynamic braking resistor protection circuit.

Furthermore, a configuration which combines MSDBR with a parallel integrated capacitor was proposed in Reference [44] to improve the performance of DFIG-WTs during the transient period. Due to the application of the proposed hybrid control scheme, the induced overvoltage in the stator will not cause the converter system to lose control. As a result, rotor overvoltage can be limited. At the same time, the DC-link capacitor charging current can be controlled to restrain DC-link overvoltage.

\subsection{Reactive Power Compensation Device}

The static var compensator (SVC) is a widely used reactive power compensation device with the configuration comprising a thyristor-controlled reactor and thyristor-switched capacitors. By injecting reactive power into the connected bus, the SVC can improve the transient stability of DFIG-WTs and damp the power oscillations in transmission lines.

The static synchronous compensator (STATCOM) is a power electronic device based on the voltage source converter principle. Generally, the STATCOM comprises a two- or three-level voltage source converter [45], as shown in Figure 14. During steady-state conditions, this device injects reactive power into or absorbs reactive power from the power grid to improve voltage regulation and stability. Thus, the transfer capability can be enhanced. To provide smooth and rapid reactive power compensation for grid voltage recovery, the STATCOM can inject the maximum reactive current into a power grid during fault conditions $[1,45,46]$. Compared with thyristor-controlled static var compensators (SVCs), the STATCOM has a similar capability in stability improvement, but a higher control bandwidth. Furthermore, the STATCOM implemented in DFIG-WTs can compensate current without depending on the voltage level of the connection point, which ensures the effective operation of the STATCOM during serious fault conditions [47-49]. A GSC controller can successfully return the DC-link voltage to a normal value with the aid of the STATCOM [50], which is a necessary condition for the RSC to restart.

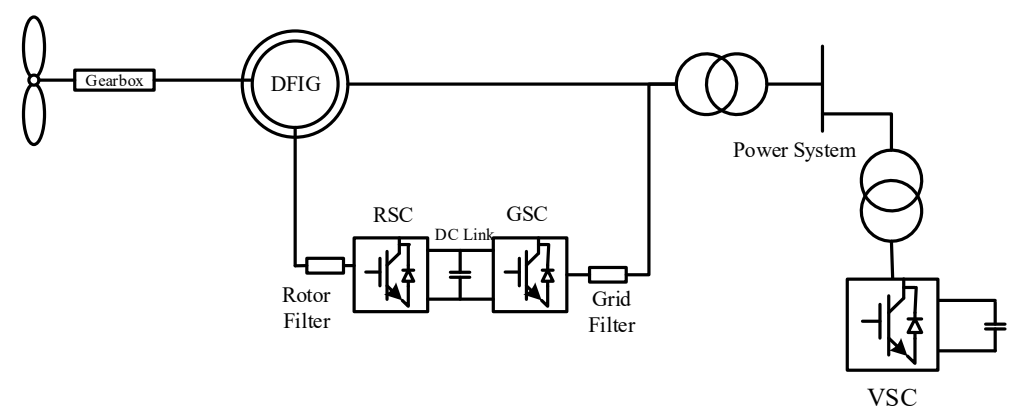

Figure 14. Static synchronous compensator (STATCOM) protection circuit. 


\subsection{Fault Current Limiter}

Fault current limiters are now commonly used in large interconnected power systems to limit overcurrent during fault conditions. In this way, generators and transmission lines can be protected from being damaged. Furthermore, the FCL can maintain terminal voltage regulation by injecting reasonable resistance into a stator circuit and providing adaptive voltage compensation A superconducting fault current limiter (SFCL) is a typical configuration in the application of superconductors. The proposed SFCL consists of a coupling transformer (CT), a controlled switch, and a superconducting coil (SC), as shown in Figure 15. In normal operation conditions, the controlled switch is closed and the flux between the two CT windings can offset each other. Thus, only the CT operation impedance is implemented in the circuit. During transient periods, the controlled switch is open, which results in the destruction of non-inductive coupling. The superconducting coil is quenched to its high-resistance state to restrict fault current [51]. Based on the operating principle of the SFCL, this device is generally installed on the stator side of DFIG-WTs to provide high resistance during transient periods [52]. Therefore, the stator overcurrent can be restrained.

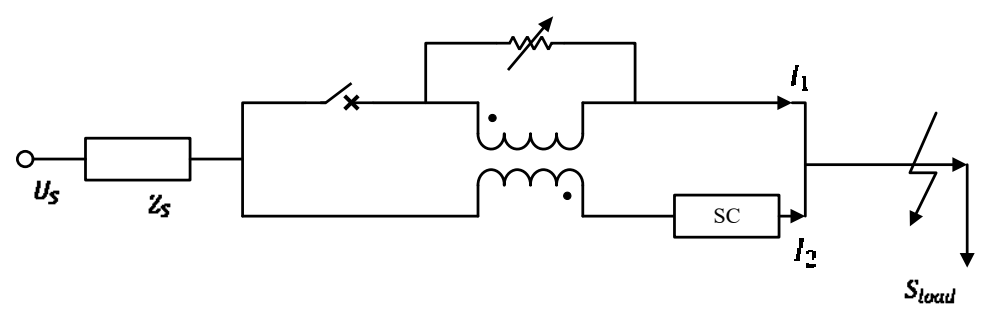

Figure 15. Superconducting fault current limiter.

The saturated-core fault current limiter (SCFCL) is another modified FCL topology which was proposed in Reference [8]. The SCFCL is mainly composed of a superconducting DC coil and a coupling transformer in which AC coils are embedded in a saturated iron core. The DC coil is located between two limbs of AC coils, as shown in Figure 16. In normal working conditions, the impedance of the SCFCL is negligible due to the saturated iron core. After a fault occurs, abruptly increased current flows through $\mathrm{AC}$ coils, resulting in the iron core becoming unsaturated. Therefore, the impedance of AC coils increases quickly, and the fault current can be restricted. The installation of an SCFCL on the stator side, as shown in Figure 17, provides flexibility in stator resistance. Due to the specific characteristics of the SCFCL, its external installation has no resistance under normal conditions but provides a high resistance during transient periods to restrain stator overcurrent and prevent voltage dips in a DFIG [53].

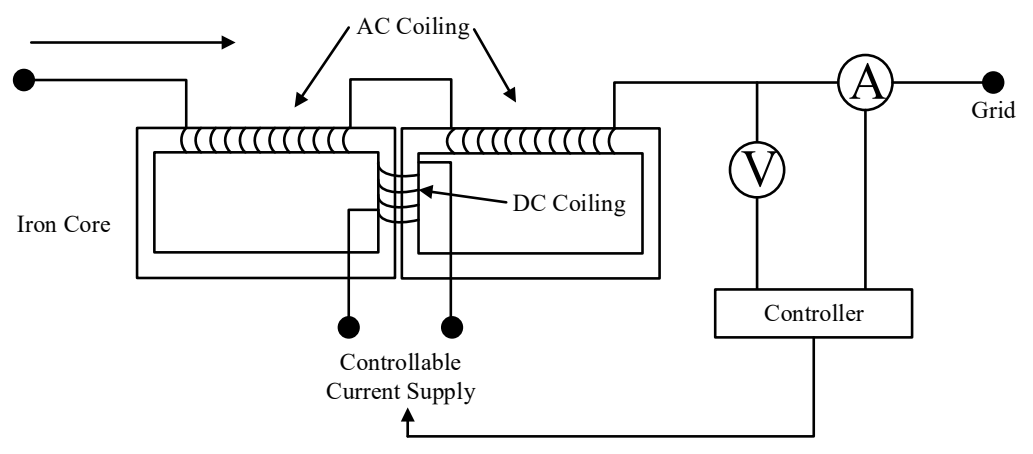

Figure 16. Saturated-core fault current limiter (SCFCL). 


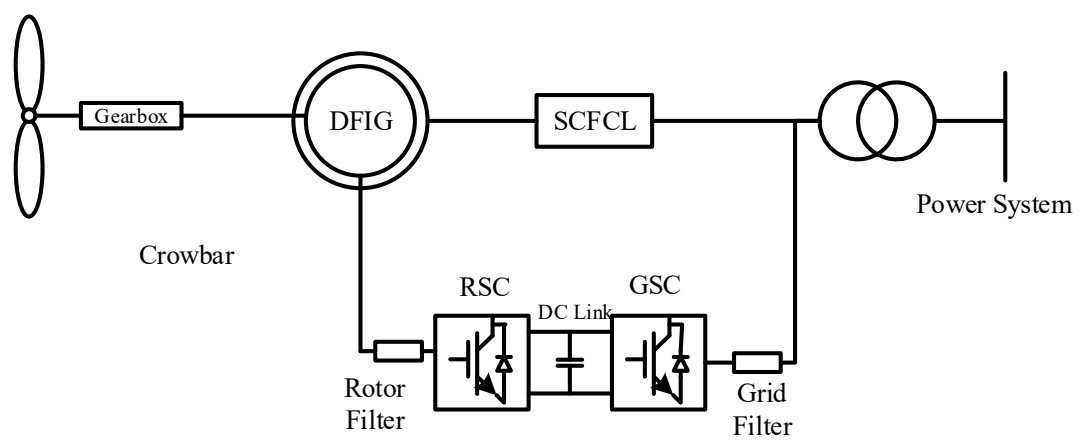

Figure 17. DFIG system with SCFCL.

A circuit configuration combining an FCL with a superconducting magnetic energy storage (SMES) was proposed in Reference [54] to enhance the LVRT capability of DFIG-WTs. During normal operation, the SMES circuit is activated to smooth the output power of wind turbines. When a fault occurs, the superconducting coil is injected into the circuit to restrain stator overcurrent. In order to eliminate power fluctuations in power systems, the FCL resistance is reduced to its initial value during post-fault periods, and the SMES-FCL returns to operating as an SMES [54].

\subsection{Series Grid-Side Converter}

The SGSC is a bidirectional power converter connected across the DC-link, as shown in Figure 18. The SGSC has the capability to regulate DC-link voltage by controlling the active power injection or absorption. Another function of the SGSC is to compensate for stator harmonic voltages by synthesizing a harmonic voltage content. In order to offset the influence of negative-sequence grid voltage, the SGSC is capable of injecting series compensation voltage to balance the stator voltage. The stator flux can also be controlled by the series voltage injection through the SGSC [55-58].

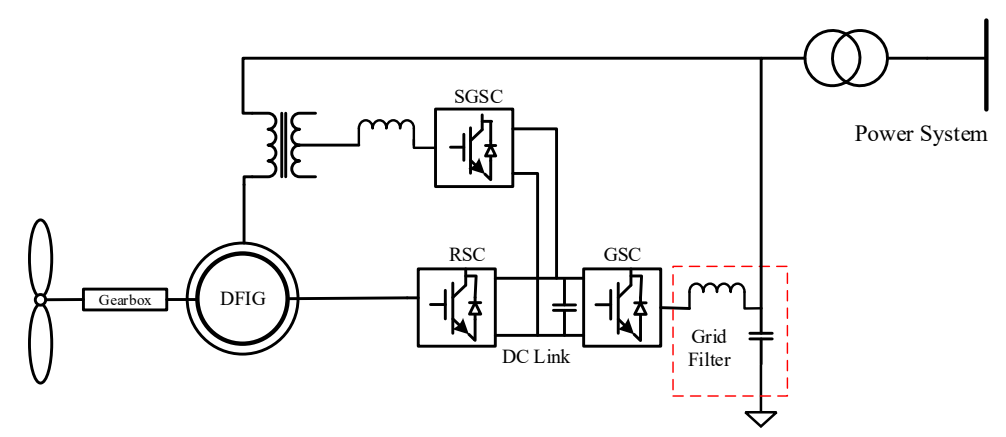

Figure 18. Series grid-side converter protection circuit.

To improve the control effect of the SGSC, an adaptive resonant controller was proposed in Reference [59]. Through voltage distortion and unbalance compensation, the hybrid controller regulates the stator voltage at its rated value even under unbalanced grid voltage conditions. The simulation results proved that this scheme could keep the stator voltage balanced and sinusoidal to enhance the generated power quality. A unified DFIG-WT architecture comprising parallel grid-side rectifiers (PGSRs) and an SGSC was proposed in Reference [60]. In this scheme, both the PGSR and the SGSC are connected to the DC-link and share the same DC bus. During sub-synchronous operation, the PGSR maintains the DC-link voltage by injecting power into the rotor circuit. The SGSC maintains the stator flux magnitude in a desirable range to meet steady-state power requirements. The hybrid control scheme equips the DFIG with the capability of unencumbered power processing and enhances the LVRT capability. 


\subsection{Comparative Results Analysis of Stator-Side External Retrofit Techniques}

Stator-side external retrofit techniques show desirable performance in maintaining the terminal voltage and restraining DC-link overvoltage. To compare the control effect of various stator-side external retrofit techniques, the same test system and fault conditions as in Section 3 were adopted. Typical models of an SDBR [44], STATCOM [50], FCL [53], and SGSC [57] were implemented in MATLAB/Simulink, and the results are shown in Figure 19. Figure 19a shows the control effect in maintaining terminal voltage. By providing fast and smooth reactive power compensation, the STATCOM provided better performance in improving the terminal voltage dynamics than the SDBR. In addition, the FCL could maintain terminal voltage regulation by injecting reasonable resistance into the stator circuit and providing adaptive voltage compensation. The SGSC focuses on keeping terminal voltage balanced and sinusoidal; thus, it is not presented in Figure 19a. Figure 19b shows the control effect of maintaining DC-link voltage. By controlling the active power injection or absorption, the SGSC can regulate DC-link voltage during grid faults. The SDBR aids the RSC and GSC in maintaining controllability of DC-link voltage. However, more serious DC-link voltage drops occurred when the SDBR was implemented in DFIG-WTs compared with the SGSC and STATCOM.

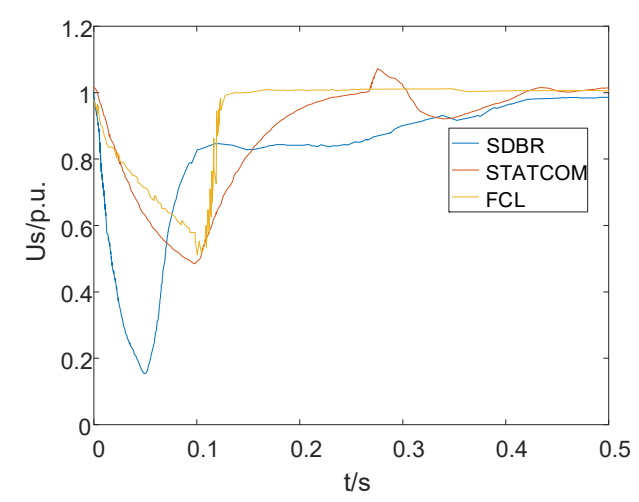

(a)

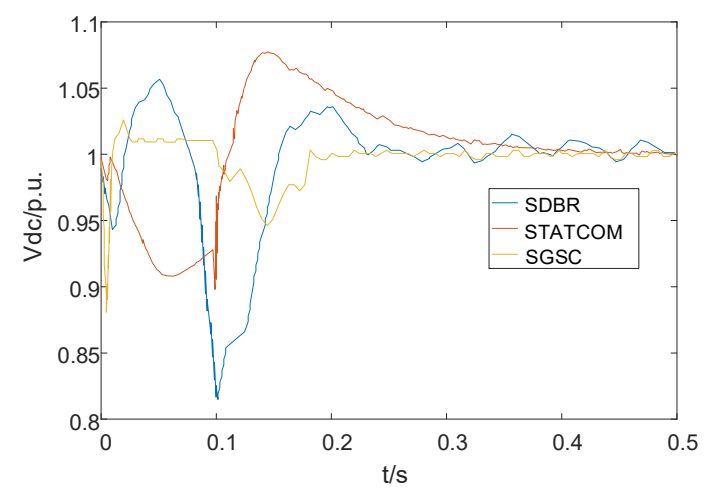

(b)

Figure 19. Control effect comparison of stator-side external retrofit techniques in (a) terminal voltage, (b) DC-link voltage.

\section{Internal Control Techniques}

In addition to implementing extra devices to enhance the LVRT capability of DFIG-WTs, the performance of DFIG-WTs during transient periods can be improved by optimizing control strategies and parameters. Various advanced control methods were applied in wind turbines, RSCs, or GSCs to make full use of the DFIG's own control capability. The application of linear control methods and nonlinear control methods can provide support during grid voltage dips.

\subsection{Wind Turbine Control}

In variable-speed wind turbines, the use of blade pitch angle (BPA) control is becoming common to control the output power and protect generators from sudden wind gusts. During normal operation, when wind speed exceeds the threshold value, blade pitch angle controllers can modify the speed of rotor windings to maintain tip speed ratio. In this case, output power can be kept at the rated value, and the electrical and mechanical stress of wind turbines can be limited [61,62].

During the transient period, grid voltage dips can lead to imbalance between the high input power from wind and the low electrical output power to the grid, which may result in overspeed. Blade pitch controllers can protect rotor windings from overspeed and possible runaway conditions. Furthermore, an advanced control technique was proposed to absorb the wind energy which cannot be injected to the power grid during faults. This control scheme converts additional power to kinetic energy of wind 
turbines by reducing rotor torque, which may also lead to the rotor speed increasing during grid faults. The blade pitch angle control is triggered once the rotor speed exceeds the threshold value. Therefore, the hybrid control scheme can improve wind energy efficiency on the premise of safe operation.

To improve the control effect during severe disturbances and avoid the torque ripple caused by conventional proportion integration differentiation (PID) controllers, adaptive fuzzy-PID controllers can be utilized in variable-speed wind turbines [63]. Fuzzy-PID controllers endow blade pitch angle controllers with the capability to maintain control even under unbalanced faults, as well as handle situations with unstable wind power.

\subsection{RSC Control}

In recent years, various internal control methods were proposed from the perspective of RSC control to enhance the LVRT capability of DFIG-WTs, as shown in Figure 20. $U_{r d}$ and $U_{r q}$ denote the $d$ - and $q$-axis RSC output voltage. RSC control methods can be classified as linear methods and nonlinear methods.

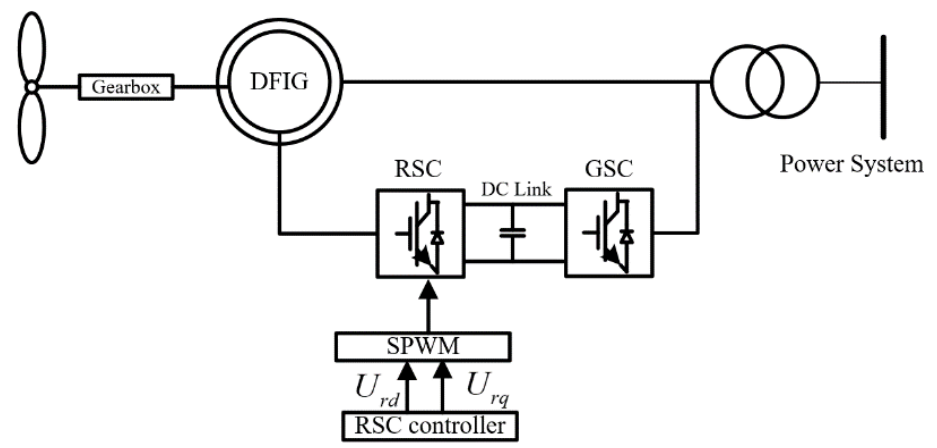

Figure 20. Rotor-side converter (RSC) controller.

\subsubsection{Linear RSC Control Methods}

Vector control is the most widely used method in DFIG to achieve the independent control of different system parameters. In vector control, the induction generator is controlled in a synchronous reference frame to decouple electromagnetic torque and rotor excitation current [64]. Moreover, the current vector is decomposed into components of stator active power and stator reactive power in the stator-flux-oriented reference frame. Typical RSC proportional-integral (PI) controllers are capable of regulating rotor speed, reactive power, and rotor current $[65,66]$. Particle swarm optimization (PSO) was proposed in Reference [67] to tune the PI controller parameters, thereby improving the control performance of PI controllers.

However, the closed-loop structure of conventional vector control may lead to complex calculation and low dynamic response in DFIGs. To solve these problems, a combined vector and direct power control (CVDPC) was proposed in Reference [66] to provide faster dynamic response, lower computation, and simpler implementation.

Based on the mechanism that DC flux can be transformed into compensation current, current compensation (CC) control was proposed in Reference [68] to improve the LVRT capability of DFIG-WTs. As an effective RSC control method, this control technique makes use of compensation current to counteract the DC flux caused by faults; thus, transient current and rotor voltage can be limited. To coordinate with the current compensation control, a crowbar circuit is installed in the DC-link to act as a release channel for extra power. The optimal active current compensation controller can effectively improve the LVRT capability of DFIG-WTs. Due to the mechanism that reasonable active current injection can significantly improve the small signal stability of DFIG-WTs, a novel optimal active and reactive current proportion method was proposed in Reference [69]. The optimal active injection current varies with the active current reference, which can be calculated from the fault position. 
Simulation and experimental results showed that the proposed scheme can effectively reduce transient peak voltage and the voltage oscillations can be reduced during transient periods.

A feedforward transient compensation (FFTC) controller was proposed in Reference [70]. Compensation terms for DFIG stator transient voltages are feedforward injected into the current control loop and power control loop to improve the control effect of DFIG-WTs in transient conditions. For the current loop, complete transient voltages are injected into the rotor-current control loop by feedforward terms to regulate the transient rotor current. For the power loop, $60-$ and $120-\mathrm{Hz}$ components are feedforward injected into the rotor current; thus, desired tracking of the rotor current is achieved. In this case, an FFTC controller can improve the capability of transient rotor current control and minimizes the DFIG control lost during both balanced and unbalanced grid faults. Therefore, the LVRT capability of DFIG-WTs can be enhanced. There are other two feedforward control methods that improve the transient capability of DFIG-WTs by adding feedforward terms: (1) feedforward current reference control (FCRC) was proposed to achieve zero-error tracking for the rotor current references after grid faults. By introducing the additional rotor current feedforward to the current loop, the rotor current can be maintained in a balanced and sinusoidal manner [71]; (2) feed-forward transient current control (FFTCC) was proposed to reduce transient current stress on the RSC and ensure that the active and reactive power supply remains uninterrupted by adding the stator flux-related feedforward components to the current loop [72].

\subsubsection{Nonlinear RSC Internal Control}

Since conventional PID controllers are designed based on linearized system models, they usually show poor performance during severe grid faults. Thus, many nonlinear control methods were proposed to provide better control effect for DFIG-WTs under large disturbances.

Sliding mode control (SMC) is an intermittent control signal-based nonlinear control method. In Reference [73], SMC was applied in DFIG-WTs to restrict the oscillations in electromagnetic torque and stator active power, which improved the system robustness. However, the application of SMC may lead to the decreasing capability to generate power under large disturbances. A decentralized nonlinear control (DNC) method was proposed in Reference [74] to improve the transient stability of DFIG-WTs. Based on the differential geometry theory, this LVRT technique can linearize the complex DFIG model and realize optimal control for DFIG-WTs. This exact linearization based method can significantly improve the LVRT capability compared to the conventional PI controller. However, due to the fluctuation in stator terminal voltage, the strict assumption of exact linearization is hard to achieve, which limits the application of the proposed method.

Input-to-state stability (ISS)-based control was applied to DFIG-WTs in Reference [75]. Based on the mechanism where the existence of ISS control Lyapunov functions can be used to demonstrate the input-to-state stability of nonlinear systems, a decentralized ISS control law was proposed for the RSC to enhance the transient stability of wind turbines. However, ISS-based controllers can only ensure the inverse optimality, while combination with other control techniques is needed to further optimize the ISS control parameters. By reasonably designing the state-dependent coefficient (SDC) matrices and weighting matrices, an effective RSC control scheme based on the state-dependent Riccati equation (SDRE) technique was proposed in Reference [19]. The implementation of the SDRE control method can simplify control and mitigate the impact of grid voltage dips. Moreover, different selections of SDC matrices lead to different control performance, whereas the extra freedom in selecting non-unique SDC matrices makes the robust $\mathrm{H} \infty$ controller design more flexible [76].

Fuzzy control can provide desirable control performance for DFIG-WTs during severe disturbances such as three-phase short-circuit faults and sudden changes in wind speed, while linear control schemes cannot predict the behavior of DFIGs correctly in this case [77,78]. The fuzzy logic controller is known for its adaptability to nonlinear systems and the function of reducing computational complexity. In Reference [78], two fuzzy logic controllers were implemented in RSCs. One was applied to control the direct current proportional to the generated reactive power, and the other was applied to control the 
quadrature current proportional to the generated active power. Simulation and experimental results showed that the fuzzy logic controller has a faster and a more accurate response when compared with PI controllers. Compared with the fuzzy logic controller, the interval type-2 fuzzy PI controller (IT2-FPI) is generally more robust and has a smoother control surface around the steady state [79]. Thus, the IT2-FPI can also be applied in DFIGs to provide ideal capability of handling uncertainties during grid voltage dips. The proposed strategy can provide a satisfactory performance in power oscillation damping without the need to retune controller parameters. Furthermore, a fuzzy operator was applied in DFIG-WTs to scale the variables of optimization including PI gains of DFIG controllers and SFCL parameters in Reference [53]. The fuzzy operator scaled the objective functions within the range of $[0,1]$, and the max-geometric mean operator aggregated the scaled objective functions. This optimization algorithm could smooth output power and improve the LVRT capability through multi-objective optimization.

\subsection{GSC Control}

The GSC is an important device with the function of controlling DC-link voltage and the reactive power exchange with the grid. With properly designed GSC controllers, DC-link overvoltage can be restricted during large grid voltage disturbances, as shown in Figure 21. $U_{g d}$ and $U_{g q}$ denote the $d$ - and $q$-axis GSC output voltage.

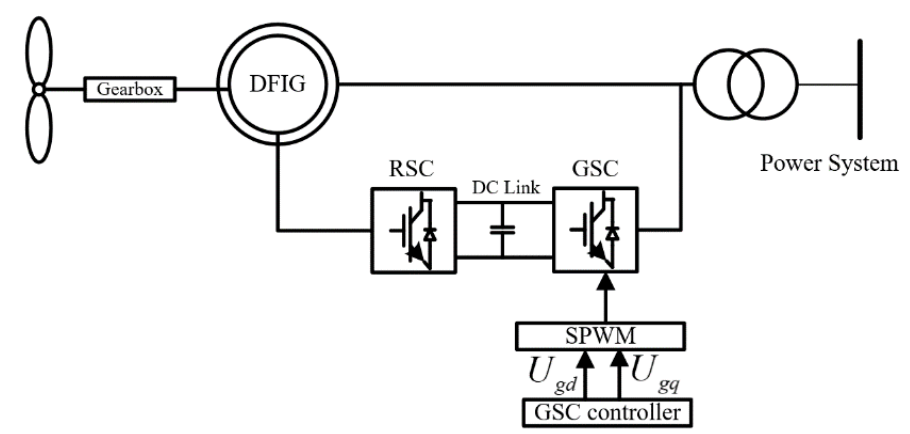

Figure 21. Grid-side converter (GSC) controller.

In Reference [80], a coordinated control method composed of a PI controller and resonant compensation was applied in DFIG-WTs to restrict torque and active power oscillations. Therefore, the dynamic performance of DFIG-WTs under unbalanced conditions could be improved. In Reference [81], a PI-DFR controller comprising a PI regulator and a dual-frequency resonant (DFR) was adopted in DFIG-WTs. By applying this coordinated control, the DC-link voltage oscillations could be restricted, and constant active power output could be ensured. Both the RSC and the GSC were controlled to provide a smooth and optimized operation.

However, the linear control methods applied in GSC cannot predict the behavior of DFIG-WTs during severe disturbances. A discrete-time inverse optimal control method based on a neural network was proposed in Reference [82] to provide better dynamic performance for DFIG-WTs. Due to the on-line identification property of neural networks, the real-time neural inverse optimal (RNIO) controller design can be achieved without system parameters given, in which case the system robustness can be improved.

Sliding mode control can also be applied in GSC internal control to alter the system dynamics. The proposed sliding mode control can control the GSC to ensure desirable DC-link voltage and steady active power output. In Reference [83], a nonlinear coordinated control method was applied to the GSC of DFIG-WTs to stabilize the internal dynamics. By using the proposed method, rotor overcurrent and DC-link overvoltage could be restrained and, thus, the LVRT capability could be enhanced. 


\subsection{Comparative Results Analysis of Internal Control Techniques}

Internal control techniques can be implemented in the RSC and GSC to restrain rotor current, restrict stator voltage oscillations, and maintain DC-link voltage. To compare the control effect of various internal control techniques, the same test system and fault conditions as in Section 3 were adopted. Furthermore, all internal techniques adopted the same active crowbar circuits during the initial fault period to avoid the influence of protection circuits, and the duration of the active crowbar was set as $0.02 \mathrm{~s}$. During the transient period, the simulation system applied five RSC control methods in DFIG-WTs for comparison: conventional PI controller, SMC method [73], DNC method [74], ISS-based controller [75], and SDRE-based controller [76]. The comparative results are shown in Figure 22. At the initial period, the terminal voltage dropped rapidly to around 0.1 p.u. due to the severe three-phase to ground fault, as shown in Figure 22c. Stator perturbations induced oscillations in rotor side, and the rotor current exceeded 2 p.u., as shown in Figure 22a. In this situation, the active crowbar circuit was activated. It can be seen from Figure 22a that the rotor current of the ISS controller and SDRE controller could be maintained at a high value to make full use of the control capability of converters. In Figure 22b, the wind farm with an SDRE controller could provide more reactive power support during the transient period. Thus, better voltage dynamics could be achieved, as shown in Figure 22c.

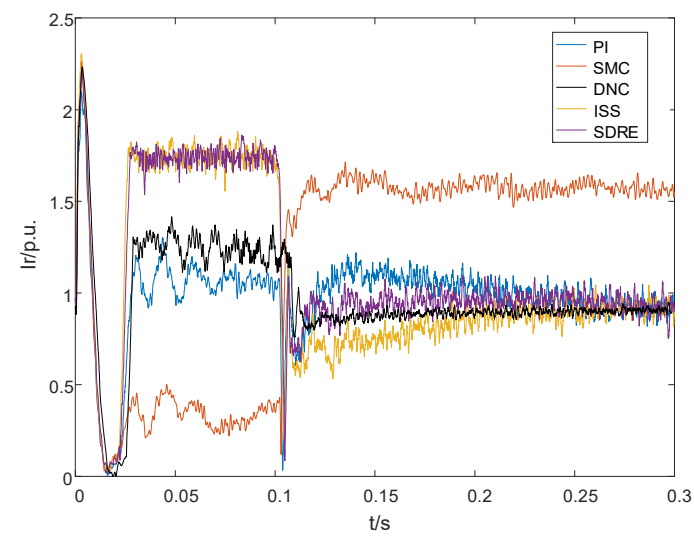

(a)

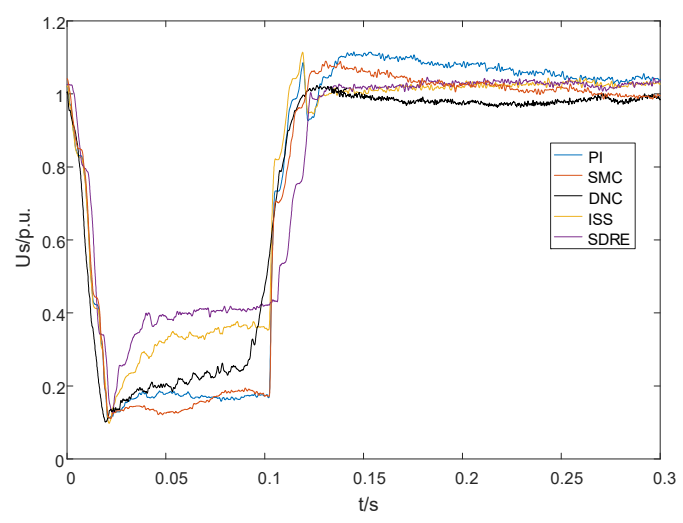

(c)

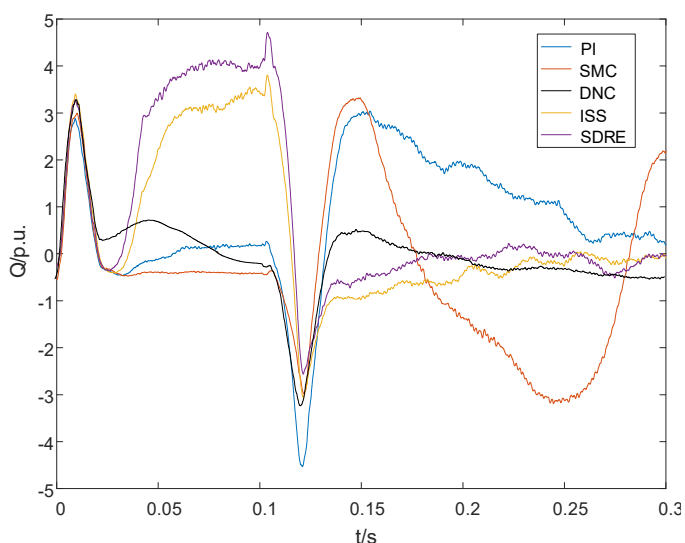

(b)

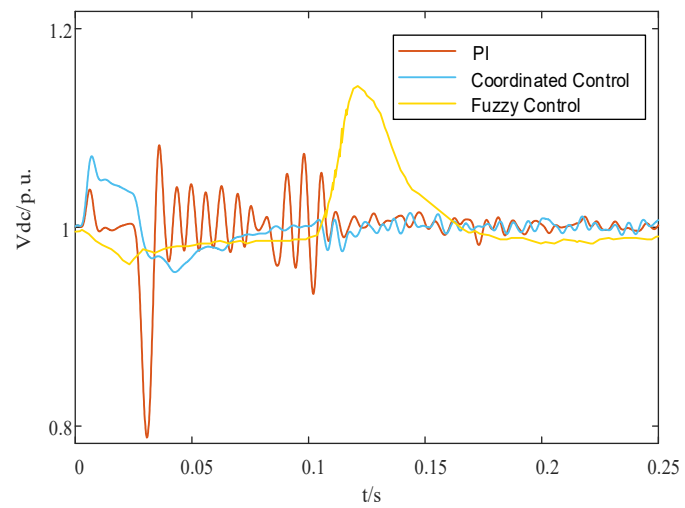

(d)

Figure 22. Control effect comparison of internal control techniques in (a) rotor current, (b) reactive power support, (c) terminal voltage, and (d) DC-link voltage. 
Since the design of RSC internal control methods pays less attention on DC-link overvoltage restriction, the SMC method, DNC method, ISS-based controller, and SDRE-based controller are not presented in the comparison of DC-link voltage dynamics. The conventional PI controller, fuzzy control method [79], and coordinated control method [83] were implemented in the simulation, and the results are shown in Figure 22d. The PI controller could effectively restrain the DC-link overvoltage in the initial fault period, but a large voltage drop occurred later, which could influence the normal operation of converters. Compared with the PI controller, the coordinated control method could significantly restrict DC-link voltage drops. Through parameter optimization, the fluctuations in DC-link voltage could be limited via the fuzzy control method during grid faults. It can be seen from Figure $22 \mathrm{~d}$ that fluctuations in DC-link voltage occurred after fault clearance. Thus, the fuzzy control method should be combined with other protection circuits such as a DC-chopper to improve the control performance.

\section{Conclusions and Future Trend Exploration}

This paper gave a comprehensive review of the proposed LVRT solutions used in DFIG-WTs, including the mature techniques applied in engineering practice and the latest theoretical achievements. All LVRT solutions were classified into three categories according to their location and the ways they work. Both advantages and disadvantages were discussed in this paper, and the modified topologies or methods were also given.

External device installations inject specific circuits into DFIG-WTs by controlling the state of electronic power switches during grid faults. In this way, the wind turbine configurations can be modified to restrain stator overcurrent and rotor overcurrent, provide power support, and restrict overvoltage, such that the LVRT capability of DFIG-WTs can be enhanced. External retrofit techniques are widely used in pre-installed wind turbines for simplicity. However, economic concerns still act as a major barrier for external retrofit techniques, and the difficulties in modifying the original control structure also restrict the application of external installations. Although external modifications are not the future direction of LVRT solutions, the installation of external LVRT devices with specific function is necessary.

Internal control techniques apply advanced control theories to strengthen the LVRT capability of DFIG-WTs. By making some compensations on voltage and current or improving the control performance in nonlinear uncertain systems, internal control modifications can provide better control effects during grid voltage dips. Because the LVRT capability of DFIG-WTs can be enhanced without any external auxiliary circuits, internal control techniques have economic advantages over external retrofit techniques. Thus, internal control techniques are preferred in newly installed wind turbines, and they have broad prospects for future development.

Inspired by the summary and comparative results in References [1] and [4], the above-discussed LVRT techniques and their effects are presented in Tables 1 and 2 to indicate the functions of various LVRT solutions. In this table, $\sqrt{ }$ indicates that the chosen LVRT technique provides effective control to eliminate the grid fault effect, - indicates that the chosen LVRT solution has no effect on the fault, and * indicates that the chosen LVRT technique may deteriorate the grid fault effect. 
Table 1. Influences of external LVRT techniques on low-voltage faults.

\begin{tabular}{|c|c|c|c|c|c|c|c|c|c|c|c|}
\hline $\begin{array}{l}\text { Active } \\
\text { Power } \\
\text { Support }\end{array}$ & $\begin{array}{l}\text { Reactive } \\
\text { Power } \\
\text { Support }\end{array}$ & $\begin{array}{l}\text { DC-Link } \\
\text { Voltage } \\
\text { Oscillations }\end{array}$ & $\begin{array}{c}\text { High } \\
\text { DC-Link } \\
\text { Voltage }\end{array}$ & $\begin{array}{c}\text { Rotor } \\
\text { Voltage } \\
\text { Oscillations }\end{array}$ & $\begin{array}{c}\text { Stator } \\
\text { Voltage } \\
\text { Oscillations }\end{array}$ & $\begin{array}{c}\text { Rotor } \\
\text { Current } \\
\text { Oscillations }\end{array}$ & $\begin{array}{c}\text { Stator } \\
\text { Current } \\
\text { Oscillations }\end{array}$ & $\begin{array}{c}\text { High } \\
\text { Rotor } \\
\text { Voltage }\end{array}$ & $\begin{array}{l}\text { High } \\
\text { Rotor } \\
\text { Current }\end{array}$ & $\begin{array}{c}\text { High } \\
\text { Stator } \\
\text { Current }\end{array}$ & $\begin{array}{c}\text { LVRT Capacity } \\
\text { Technique }\end{array}$ \\
\hline- & * & - & $\sqrt{ }$ & - & * & $\sqrt{ }$ & - & - & $\sqrt{ }$ & - & Rotor crowbar \\
\hline- & - & $\sqrt{ }$ & $\sqrt{ }$ & - & - & - & - & - & * & - & DC-chopper \\
\hline- & $\sqrt{ }$ & - & $\sqrt{ }$ & - & $\sqrt{ }$ & - & - & $\sqrt{ }$ & $\sqrt{ }$ & - & Series dynamic resistor \\
\hline$\sqrt{ }$ & $\sqrt{ }$ & $\sqrt{ }$ & $\sqrt{ }$ & - & $\sqrt{ }$ & * & $\sqrt{ }$ & - & $*$ & $\sqrt{ }$ & Energy storage system \\
\hline- & - & $\sqrt{ }$ & $\sqrt{ }$ & - & $\sqrt{ }$ & - & - & $\sqrt{ }$ & - & - & $\begin{array}{cc}\text { Series } & \text { braking } \\
\text { dynamic } & \text { resistor }\end{array}$ \\
\hline- & $\sqrt{ }$ & $\sqrt{ }$ & $\sqrt{ }$ & - & $\sqrt{ }$ & - & * & - & - & * & STATCOM \\
\hline- & - & - & - & - & $\sqrt{ }$ & - & - & - & - & $\sqrt{ }$ & Fault current limiter \\
\hline$\sqrt{ }$ & - & $\sqrt{ }$ & $\sqrt{ }$ & - & $\sqrt{ }$ & - & - & - & - & - & $\begin{array}{l}\text { Series grid side } \\
\text { converter }\end{array}$ \\
\hline
\end{tabular}


Table 2. Influences of internal LVRT techniques on low-voltage faults. BPA—blade pitch angle; CC—capacitor crowbar; SMC—sliding mode control; DNC—decentralized nonlinear control; ISS—input-to-state stability; SDRE—state-dependent Riccati equation; PI—proportional-integral; DFR—dual-frequency resonant; RNIO—real-time neural inverse optimal.

\begin{tabular}{|c|c|c|c|c|c|c|c|c|c|c|c|}
\hline $\begin{array}{l}\text { Active } \\
\text { Power } \\
\text { Support }\end{array}$ & $\begin{array}{c}\text { Reactive } \\
\text { Power } \\
\text { Support }\end{array}$ & $\begin{array}{c}\text { DC-Link } \\
\text { Voltage } \\
\text { Oscillations }\end{array}$ & $\begin{array}{c}\text { High } \\
\text { DC-Link } \\
\text { Voltage }\end{array}$ & $\begin{array}{c}\text { Rotor } \\
\text { Voltage } \\
\text { Oscillations }\end{array}$ & $\begin{array}{c}\text { Stator } \\
\text { Voltage } \\
\text { Oscillations }\end{array}$ & $\begin{array}{c}\text { Rotor } \\
\text { Current } \\
\text { Oscillations }\end{array}$ & $\begin{array}{c}\text { Stator } \\
\text { Current } \\
\text { Oscillations }\end{array}$ & $\begin{array}{c}\text { High } \\
\text { Rotor } \\
\text { Voltage }\end{array}$ & $\begin{array}{c}\text { High } \\
\text { Rotor } \\
\text { Current }\end{array}$ & $\begin{array}{c}\text { High } \\
\text { Stator } \\
\text { Current }\end{array}$ & $\begin{array}{c}\text { LVRT } \\
\text { Capacity } \\
\text { Technique }\end{array}$ \\
\hline * & * & $\sqrt{ }$ & $\sqrt{ }$ & $\sqrt{ }$ & $\sqrt{ }$ & $\sqrt{ }$ & $\sqrt{ }$ & $\sqrt{ }$ & $\sqrt{ }$ & $\sqrt{ }$ & $\begin{array}{c}\text { BPA } \\
\text { control }\end{array}$ \\
\hline- & - & $\sqrt{ }$ & $\sqrt{ }$ & - & - & $\sqrt{ }$ & $\sqrt{ }$ & - & $\sqrt{ }$ & - & $\begin{array}{l}\text { Vector } \\
\text { control }\end{array}$ \\
\hline- & - & $\sqrt{ }$ & $\sqrt{ }$ & $\sqrt{ }$ & $\sqrt{ }$ & - & $\sqrt{ }$ & $\sqrt{ }$ & - & - & CC control \\
\hline$\sqrt{ }$ & $\sqrt{ }$ & - & - & - & - & $\sqrt{ }$ & - & - & $\sqrt{ }$ & - & $\begin{array}{l}\text { Feedforward } \\
\text { control }\end{array}$ \\
\hline- & - & - & - & - & - & $\sqrt{ }$ & $\sqrt{ }$ & $\sqrt{ }$ & $\sqrt{ }$ & - & $\begin{array}{c}\text { SMC } \\
\text { control }\end{array}$ \\
\hline$\sqrt{ }$ & $\sqrt{ }$ & - & - & $\sqrt{ }$ & $\sqrt{ }$ & $\sqrt{ }$ & $\sqrt{ }$ & - & - & - & $\begin{array}{l}\text { DNC } \\
\text { control }\end{array}$ \\
\hline$\sqrt{ }$ & $\sqrt{ }$ & - & - & $\sqrt{ }$ & $\sqrt{ }$ & $\sqrt{ }$ & $\sqrt{ }$ & $\sqrt{ }$ & - & - & ISS control \\
\hline$\sqrt{ }$ & $\sqrt{ }$ & - & - & $\sqrt{ }$ & $\sqrt{ }$ & $\sqrt{ }$ & $\sqrt{ }$ & $\sqrt{ }$ & $\sqrt{ }$ & - & $\begin{array}{l}\text { SDRE } \\
\text { control }\end{array}$ \\
\hline- & - & $\sqrt{ }$ & $\sqrt{ }$ & - & - & $\sqrt{ }$ & $\sqrt{ }$ & - & $\sqrt{ }$ & $\sqrt{ }$ & $\begin{array}{l}\text { Fuzzy } \\
\text { control }\end{array}$ \\
\hline$\sqrt{ }$ & - & - & - & - & - & $\sqrt{ }$ & $\sqrt{ }$ & - & - & $\sqrt{ }$ & $\begin{array}{c}\text { PI-R } \\
\text { control }\end{array}$ \\
\hline$\sqrt{ }$ & - & $\sqrt{ }$ & $\sqrt{ }$ & - & - & $\sqrt{ }$ & $\sqrt{ }$ & - & - & $\sqrt{ }$ & $\begin{array}{l}\text { PI-DFR } \\
\text { control }\end{array}$ \\
\hline- & - & $\sqrt{ }$ & $\sqrt{ }$ & - & - & - & - & - & - & - & $\begin{array}{c}\text { RNIO } \\
\text {-coordinated }\end{array}$ \\
\hline- & - & - & $\sqrt{ }$ & - & - & - & - & - & $\sqrt{ }$ & - & $\begin{array}{c}\text { control in } \\
\text { Reference } \\
\text { [83] }\end{array}$ \\
\hline
\end{tabular}


In terms of advantages in the cost factor and the flexibility in modification, internal control techniques will make substantial progress in the future. New control theories will also be proposed to provide more flexible and effective performance during grid voltage dips. The LVRT solutions combined with artificial intelligence will be a hot field. For example, artificial intelligence techniques can endow DFIG-WTs with the ability to achieve on-line optimal tuning, and supplementary learning structures can be implemented in DFIG-WTs to improve the LVRT capability. In addition, external protection circuits combined with internal control techniques should be studied in detail to meet the requirement of modifying existing DFIG-WTs.

Author Contributions: Conceptualization, B.Q.; methodology, B.Q., H.L., and W.L.; software, H.L. and B.Q.; validation, H.L. and X.Z.; investigation, H.L. and J.L.; writing-original draft preparation, B.Q., H.L. and X.Z.; writing-review and editing, H.L., X.Z., W.L., and J.L.; supervision, B.Q. All authors have read and agreed to the published version of the manuscript.

Funding: This work was funded by the National Natural Science Foundation of China (51707147, U1766215), the Key Research and Development Program of Shaanxi (2017ZDCXL-GY-02-03), and the Project of Shaanxi Electric Power Corporation (B626KY190005)

Conflicts of Interest: The authors declare no conflicts of interest.

\section{References}

1. Jerin, A.R.A.; Kaliannan, P.; Subramaniam, U.; El Moursi, M.S. A Review on FRT solutions for improving transient stability in DFIG-WTs. IET Renew. Power Gener. 2018, 12, 1786-1799. [CrossRef]

2. Kaloi, G.; Baloch, M.; Kumar, M.; Soomro, D.; Chauhdary, S.; Memon, A.; Ishak, D. An LVRT Scheme for Grid Connected DFIG Based WECS Using State Feedback Linearization Control Technique. Electronics 2019, 8, 777. [CrossRef]

3. Baloch, M.H.; Ishak, D.; Chaudary, S.T.; Ali, B.; Memon, A.A.; Jumani, T.A. Wind Power Integration: An Experimental Investigation for Powering Local Communities. Energies 2019, 12, 621. [CrossRef]

4. Saeed, M.A.; Khan, H.M.; Ashraf, A.; Qureshi, S.A. Analyzing effectiveness of LVRT techniques for DFIG wind turbine system and implementation of hybrid combination with control schemes. Renew. Sustain. Energy Rev. 2018, 81, 2487-2501. [CrossRef]

5. Hansen, A.D.; Iov, F.; Blaabjerg, F.; Hansen, L. Review of Contemporary Wind Turbine Concepts and Their Market Penetration. Wind Eng. 2004, 28, 247-263. [CrossRef]

6. Chondrogiannis, S.; Barnes, M. Stability of doubly-fed induction generator under stator voltage orientated vector control. IET Renew. Power Gener. 2008, 2, 170-180. [CrossRef]

7. Rahimi, M.; Parniani, M. Grid-fault ride-through analysis and control of wind turbines with doubly fed induction generators. Electr. Power Syst. Res. 2010, 80, 184-195. [CrossRef]

8. Tripathi, P.M.; Sahoo, S.S.; Chatterjee, K. Enhancing the fault ride through capability of DFIG-based wind energy system using saturated core fault current limiter. J. Eng. 2019, 2019, 4916-4921. [CrossRef]

9. Mohseni, M.; Islam, S.M. Review of international grid codes for wind power integration: Diversity, technology and a case for global standard. Renew. Sustain. Energy Rev. 2012, 16, 3876-3890. [CrossRef]

10. Zhang, L.; Cai, X.; Guo, J. Dynamic Responses of DFIG Fault Currents Under Constant AC Exitation Condition. In Proceedings of the 2009 Asia-Pacific Power and Energy Engineering Conference, Wuhan, China, 27-31 March 2009; pp. 1-4. [CrossRef]

11. Wang, M.; Xu, W.; Jia, H.; Yu, X. A new control system to strengthen the LVRT capacity of DFIG based on both crowbar and DC chopper circuits. In Proceedings of the IEEE PES Innovative Smart Grid Technologies, Tianjin, China, 21-24 May 2012; pp. 1-6. [CrossRef]

12. El Moursi, M.S.; Goweily, K.; Kirtley, J.L.; Abdel-Rahman, M. Application of Series Voltage Boosting Schemes for Enhanced Fault Ridethrough Performance of Fixed Speed Wind Turbines. IEEE Trans. Power Deliv. 2014, 29, 61-71. [CrossRef]

13. Alsmadi, Y.M.; Xu, L.; Blaabjerg, F.; Ortega, A.J.; Wang, A. Comprehensive analysis of the dynamic behavior of grid-connected DFIG-based wind turbines under LVRT conditions. In Proceedings of the 2015 IEEE Energy Conversion Congress and Exposition (ECCE), Montreal, QC, Canada, 20-24 September 2015; pp. 4178-4187. [CrossRef] 
14. Farhadi-Kangarlu, M.; Babaei, E.; Blaabjerg, F. A comprehensive review of dynamic voltage restorers. Int. J. Electr. Power Energy Syst. 2017, 92, 136-155. [CrossRef]

15. Alsmadi, Y.M.; Xu, L.; Blaabjerg, F.; Ortega, A.J.; Abdelaziz, A.Y.; Wang, A.; Albataineh, Z. Detailed Investigation and Performance Improvement of the Dynamic Behavior of Grid-Connected DFIG-Based Wind Turbines Under LVRT Conditions. IEEE Trans. Ind. Appl. 2018, 54, 4795-4812. [CrossRef]

16. Niu, L.; Wang, X.; Wu, L.; Yan, F.; Xu, M. Review of low voltage ride-through technology of doubly-fed induction generator. J. Eng. 2019, 2019, 3106-3108. [CrossRef]

17. Wen, H.; Cai, S. Modeling and LVRT analysis of DFIG wind power system. In Proceedings of the 2015 IEEE PES Asia-Pacific Power and Energy Engineering Conference (APPEEC), Brisbane, Australia, 15-18 November 2015; pp. 1-5. [CrossRef]

18. Yang, J.; Fletcher, J.E.; O'Reilly, J. A series dynamic resistor based converter protection scheme for doubly-fed induction generator during various fault conditions. In Proceedings of the 2009 IEEE Power \& Energy Society General Meeting, Calgary, AB, Canada, 26-30 July 2009; pp. 1-8. [CrossRef]

19. Qin, B.; Sun, H.; Ma, J.; Li, W.; Ding, T.; Wang, Z.; Zomaya, A.Y. Robust Ho Control of Doubly Fed Wind Generator via State-Dependent Riccati Equation Technique. IEEE Trans. Power Syst. 2019, 34, 2390-2400. [CrossRef]

20. Justo, J.J.; Bansal, R.C. Parallel R-L configuration crowbar with series R-L circuit protection for LVRT strategy of DFIG under transient-state. Electr. Power Syst. Res. 2018, 154, 299-310. [CrossRef]

21. Jin, C.; Wang, P. Enhancement of low voltage ride-through capability for wind turbine driven DFIG with active crowbar and battery energy storage system. In Proceedings of the IEEE PES General Meeting, Providence, RI, USA, 25-29 July 2010; pp. 1-8. [CrossRef]

22. Vidal, J.; Arza, G.A.J.; Aurtenechea, S. Single-Phase DC Crowbar Topologies for Low Voltage Ride Through Fulfillment of High-Power Doubly Fed Induction Generator-Based Wind Turbines. IEEE Trans. Energy Convers. 2013, 28, 768-781. [CrossRef]

23. Din, Z.; Zhang, J.; Zhu, Y.; Xu, Z.; El-Naggar, A. Impact of Grid Impedance on LVRT Performance of DFIG System with Rotor Crowbar Technology. IEEE Access 2019, 7, 127999-128008. [CrossRef]

24. Guo, W.; Xiao, L.; Dai, S.; Xu, X.; Li, Y.; Wang, Y. Evaluation of the Performance of BTFCLs for Enhancing LVRT Capability of DFIG. IEEE Trans. Power Electron. 2015, 30, 3623-3637. [CrossRef]

25. Okedu, K.E.; Muyeen, S.M.; Takahashi, R.; Tamura, J. Wind Farms Fault Ride Through Using DFIG With New Protection Scheme. IEEE Trans. Sustain. Energy 2012, 3, 242-254. [CrossRef]

26. Islam, M.R.; Ajom, M.G.; Sheikh, M.R.I. Application of DC Chopper to Augment Fault Ride Through of DFIG Based Wind Turbine. In Proceedings of the 2017 2nd International Conference on Electrical Electronic Engineering (ICEEE), Rajshahi, Bangladesh, 27-29 December 2017; pp. 1-4. [CrossRef]

27. Naderi, S.B.; Negnevitsky, M.; Muttaqi, K.M. A Modified DC Chopper for Limiting the Fault Current and Controlling the DC-Link Voltage to Enhance Fault Ride-Through Capability of Doubly-Fed Induction-Generator-Based Wind Turbine. IEEE Trans. Ind. Appl. 2019, 55, 2021-2032. [CrossRef]

28. Gray, C.; Buque, C.; Chowdhury, S. AC series dynamic resistor protection scheme with switching control for doubly fed induction generator based WECS. In Proceedings of the 2016 IEEE Power and Energy Society General Meeting (PESGM), Boston, MA, USA, 17-21 July 2016; pp. 1-5. [CrossRef]

29. Yang, J.; Fletcher, J.E.; O'Reilly, J. A Series-Dynamic-Resistor-Based Converter Protection Scheme for Doubly-Fed Induction Generator during Various Fault Conditions. IEEE Trans. Energy Convers. 2010, 25, 422-432. [CrossRef]

30. Sun, L.; Meng, N.; Xu, B. Analysis of fault ride-through of doubly-fed wind power generator based on rotor series resistor. In Proceedings of the IECON 2016-42nd Annual Conference of the IEEE Industrial Electronics Society, Florence, Italy, 23-26 October 2016; pp. 1900-1905. [CrossRef]

31. Haidar, A.M.A.; Muttaqi, K.M.; Hagh, M.T. A Coordinated Control Approach for DC link and Rotor Crowbars to Improve Fault Ride-Through of DFIG-Based Wind Turbine. IEEE Trans. Ind. Appl. 2017, 53, 4073-4086. [CrossRef]

32. Kim, Y.; Zhao, J.; Harrington, R.J. Performance analysis of energy storage systems connected to a doubly fed induction generator. In Proceedings of the 2015 IEEE Green Energy and Systems Conference (IGESC), Long Beach, CA, USA, 9 November 2015; pp. 30-34. [CrossRef]

33. Kim, J.; Muljadi, E.; Gevorgian, V.; Hoke, A.F. Dynamic Capabilities of an Energy Storage-Embedded DFIG System. IEEE Trans. Ind. Appl. 2019, 55, 4124-4134. [CrossRef] 
34. Wang, X.; Sun, D.; Zhao, C.; Nian, H.; Fan, Y. A Collaborative Control Strategy of DFIG System with Energy Storage in Weak Grid. In Proceedings of the 2019 22nd International Conference on Electrical Machines and Systems (ICEMS), Harbin, China, 11-14 August 2019; pp. 1-6. [CrossRef]

35. Tourou, P.; Chhor, J.; Günther, K.; Sourkounis, C. Energy storage integration in DFIG-based wind energy conversion systems for improved fault ride-through capability. In Proceedings of the 2017 IEEE 6th International Conference on Renewable Energy Research and Applications (ICRERA), San Diego, CA, USA, 5-8 November 2017; pp. 374-377. [CrossRef]

36. Shen, Y.; Ke, D.; Sun, Y.; Kirschen, D.; Qiao, W.; Deng, X. Advanced Auxiliary Control of an Energy Storage Device for Transient Voltage Support of a Doubly Fed Induction Generator. IEEE Trans. Sustain. Energy 2016, 7, 63-76. [CrossRef]

37. Noureldeen, O.; Youssef, M.M.M. Constant Power-Control of DFIG Wind Farm with LVRT Improvement during Extreme Gust Using Super-Capacitors. In Proceedings of the 2018 Twentieth International Middle East Power Systems Conference (MEPCON), Cairo, Egypt, 18-20 December 2018; pp. 515-521. [CrossRef]

38. Döşoğlu, M.K.; Özkaraca, O.; Güvenç, U. Novel active-passive compensator-supercapacitor modeling for low-voltage ride-through capability in DFIG-based wind turbines. Electr. Eng. 2019, 101, 1119-1132. [CrossRef]

39. Hao, X.; Zhou, T.; Wang, J.; Yang, X. A hybrid adaptive fuzzy control strategy for DFIG-based wind turbines with super-capacitor energy storage to realize short-term grid frequency support. In Proceedings of the 2015 IEEE Energy Conversion Congress and Exposition (ECCE), Montreal, QC, Canada, 20-24 September 2015; pp. 1914-1918. [CrossRef]

40. Alam, M.S.; Hossain, M.I.; Hossain, M.A.; Choudhory, M.S.H.; Uddin, M.A. Protection of Inverter-based Distributed Generation with Series Dynamic Braking Resistor: A Variable Duty Control Approach. In Proceedings of the 2018 10th International Conference on Electrical and Computer Engineering (ICECE), Dhaka, Bangladesh, 20-22 December 2018; pp. 253-256. [CrossRef]

41. Causebrook, A.; Atkinson, D.J.; Jack, A.G. Fault Ride-Through of Large Wind Farms Using Series Dynamic Braking Resistors (March 2007). IEEE Trans. Power Syst. 2007, 22, 966-975. [CrossRef]

42. Huang, P.-H.; el Moursi, M.S.; Hasen, S.A. Novel Fault Ride-Through Scheme and Control Strategy for Doubly Fed Induction Generator-Based Wind Turbine. IEEE Trans. Energy Convers. 2015, 30, $635-645$. [CrossRef]

43. Keshavarzi, M.D.; Ali, M.H. FRT Capability Enhancement of Autonomous AC/DC Hybrid Microgrid by Coordinated MSDBR and Interlinking Converter Control Strategy. In Proceedings of the 2019 IEEE Power Energy Society Innovative Smart Grid Technologies Conference (ISGT), Washington, DC, USA, 18-21 February 2019; pp. 1-5. [CrossRef]

44. Okedu, K.E. Enhancing the performance of DFIG variable speed wind turbine using a parallel integrated capacitor and modified modulated braking resistor. Transm. Distrib. IET Gener. 2019, 13, 3378-3387. [CrossRef]

45. Acha, E. Power Electronic Control in Electrical Systems; Newnes Power Engineering Series: Oxford, UK, 2002.

46. Kanchanaharuthai, A.; Chankong, V.; Loparo, K.A. Transient Stability and Voltage Regulation in Multimachine Power Systems Vis-à-Vis STATCOM and Battery Energy Storage. IEEE Trans. Power Syst. 2015, 30, $2404-2416$. [CrossRef]

47. Li, N.; Wang, L.; Yang, H.; Ma, H. Stability Analysis for SSR of DFIG-Based Wind Farm Considering STATCOM Capacity Constraint. In Proceedings of the 2019 22nd International Conference on Electrical Machines and Systems (ICEMS), Harbin, China, 11-14 August 2019; pp. 1-6. [CrossRef]

48. Molinas, M.; Suul, J.A.; Undeland, T. Low Voltage Ride Through of Wind Farms With Cage Generators: STATCOM Versus SVC. IEEE Trans. Power Electron. 2008, 23, 1104-1117. [CrossRef]

49. Tang, Y.; He, H.; Ni, Z.; Wen, J.; Huang, T. Adaptive Modulation for DFIG and STATCOM With High-Voltage Direct Current Transmission. IEEE Trans. Neural Netw. Learn. Syst. 2016, 27, 1762-1772. [CrossRef] [PubMed]

50. Qiao, W.; Venayagamoorthy, G.K.; Harley, R.G. Real-Time Implementation of a STATCOM on a Wind Farm Equipped With Doubly Fed Induction Generators. IEEE Trans. on Ind. Appl. 2009, 45, 98-107. [CrossRef]

51. Chen, L.; Deng, C.; Zheng, F.; Li, S.; Liu, Y.; Liao, Y. Fault Ride-Through Capability Enhancement of DFIG-Based Wind Turbine with a Flux-Coupling-Type SFCL Employed at Different Locations. IEEE Trans. Appl. Supercond. 2015, 25, 1-5. [CrossRef] 
52. Lim, S.; Ahn, H.; Park, C. Study on Fault Current Limiting Characteristics of an SFCL Using Magnetic Coupling of Two Coils With Mechanical Switch Driven by Electromagnetic Repulsion Force. IEEE Trans. Appl. Supercond. 2014, 24,1-4. [CrossRef]

53. Sedighizadeh, M.; Yarmohammadi, H.; Esmaili, M. Enhancing FRT performance and smoothing output power of DFIG wind farm equipped by SFCL and SMES in a fuzzy framework. Eng. Sci. Technol. Int. J. 2019, 22, 801-810. [CrossRef]

54. Ngamroo, I.; Karaipoom, T. Improving Low-Voltage Ride-Through Performance and Alleviating Power Fluctuation of DFIG Wind Turbine in DC Microgrid by Optimal SMES With Fault Current Limiting Function. IEEE Trans. Appl. Supercond. 2014, 24,1-5. [CrossRef]

55. Gontijo, G.F.; Cardoso, T.T.; Francisco, D.T.; Krejci, D.; França, B.W.; Aredes, M.; Guerrero, J.M. Modeling, Control and Experimental Verification of a DFIG with a Series-Grid-Side Converter with Voltage Sag, Unbalance and Distortion Compensation Capabilities. IEEE Trans. Ind. Appl. 2019, 56, 584-600. [CrossRef]

56. Yao, J.; Li, H.; Chen, Z.; Xia, X.; Chen, X.; Li, Q.; Liao, Y. Enhanced Control of a DFIG-Based Wind-Power Generation System with Series Grid-Side Converter under Unbalanced Grid Voltage Conditions. IEEE Trans. Power Electron. 2013, 28, 3167-3181. [CrossRef]

57. Omar, S.; Helal, A.; Elarabawy, I. Stator voltage sensorless DFIG with low voltage ride-through capability using series and parallel grid side converters. In Proceedings of the 2016 7th International Renewable Energy Congress (IREC), Hammamet, Tunisia, 22-24 March 2016; pp. 1-6. [CrossRef]

58. Flannery, P.S.; Venkataramanan, G. Unbalanced Voltage Sag Ride-Through of a Doubly Fed Induction Generator Wind Turbine with Series Grid-Side Converter. IEEE Trans. Ind. Appl. 2009, 45, 1879-1887. [CrossRef]

59. Gontijo, G.; Tricarico, T.; Krejci, D.; França, B.; Aredes, M. A novel stator voltage distortion and unbalance compensation of a DFIG with series grid side converter using adaptive resonant controllers. In Proceedings of the 2017 Brazilian Power Electronics Conference (COBEP), Juiz de Fora, Brazil, 19-22 November 2017; pp. 1-6. [CrossRef]

60. Flannery, P.S.; Venkataramanan, G. A Fault Tolerant Doubly Fed Induction Generator Wind Turbine Using a Parallel Grid Side Rectifier and Series Grid Side Converter. IEEE Trans. Power Electron. 2008, 23, 1126-1135. [CrossRef]

61. Elnaghi, B.E.; Dessouki, M.E.; Elkader, F.A. Experimental investigation of pitch angle controller for DFIG based wind energy conversion system. In Proceedings of the 2017 Nineteenth International Middle East Power Systems Conference (MEPCON), Cairo, Egypt, 19-21 December 2017; pp. 1477-1482. [CrossRef]

62. Zhang, Y.; Muljadi, E.; Kosterev, D.; Singh, M. Wind Power Plant Model Validation Using Synchrophasor Measurements at the Point of Interconnection. IEEE Trans. Sustain. Energy 2015, 6, 984-992. [CrossRef]

63. Ali, M.M.M.; Youssef, A.-R.; Abdel-Gaber, G.; Ali, A.S. Adaptive Fuzzy-PID Based Pitch Angle Control of Wind Turbine. In Proceedings of the 2018 Twentieth International Middle East Power Systems Conference (MEPCON), Cairo, Egypt, 18-20 December 2018; pp. 1110-1114. [CrossRef]

64. Guo, F.; Zheng, T.; Wang, Z. Comparative study of direct power control with vector control for rotor side converter of DFIG. In Proceedings of the 9th IET International Conference on Advances in Power System Control, Operation and Management (APSCOM 2012), Hong Kong, China, 18-21 November 2012; pp. 1-6. [CrossRef]

65. Yang, L.; Xu, Z.; Ostergaard, J.; Dong, Z.; Wong, K.P. Advanced Control Strategy of DFIG Wind Turbines for Power System Fault Ride Through. IEEE Trans. Power Syst. 2012, 27, 713-722. [CrossRef]

66. Mohammadi, J.; Vaez-Zadeh, S.; Afsharnia, S.; Daryabeigi, E. A Combined Vector and Direct Power Control for DFIG-Based Wind Turbines. IEEE Trans. Sustain. Energy 2014, 5, 767-775. [CrossRef]

67. Ruiz-Cruz, R.; Sanchez, E.N.; Ornelas-Tellez, F.; Loukianov, A.G.; Harley, R.G. Particle Swarm Optimization for Discrete-Time Inverse Optimal Control of a Doubly Fed Induction Generator. IEEE Trans. Cybern. 2013, 43, 1698-1709. [CrossRef]

68. Chen, J.; Xue, A.; Tian, C.; Bi, T.; Gao, C. A new method to improve the LVRT of DFIG based on the current compensation. In Proceedings of the 30th Chinese Control Conference, Yantai, China, 22-24 July 2011; pp. 5148-5152.

69. Liu, R.; Yao, J.; Wang, X.; Sun, P.; Pei, J.; Hu, J. Dynamic Stability Analysis and Improved LVRT Schemes of DFIG-Based Wind Turbines during a Symmetrical Fault in a Weak Grid. IEEE Trans. Power Electron. 2020, 35, 303-318. [CrossRef] 
70. Liang, J.; Howard, D.F.; Restrepo, J.A.; Harley, R.G. Feedforward Transient Compensation Control for DFIG Wind Turbines during both Balanced and Unbalanced Grid Disturbances. IEEE Trans. Ind. Appl. 2013, 49, 1452-1463. [CrossRef]

71. Zhu, D.; Zou, X.; Zhou, S.; Dong, W.; Kang, Y.; Hu, J. Feedforward Current References Control for DFIG-Based Wind Turbine to Improve Transient Control Performance During Grid Faults. IEEE Trans. Energy Convers. 2018, 33, 670-681. [CrossRef]

72. Liang, J.; Qiao, W.; Harley, R.G. Feed-Forward Transient Current Control for Low-Voltage Ride-Through Enhancement of DFIG Wind Turbines. IEEE Trans. Energy Convers. 2010, 25, 836-843. [CrossRef]

73. Chen, S.; Cheung, N.C.; Wong, K.; Jie, W. Integral Sliding-Mode Direct Torque Control of Doubly-Fed Induction Generators under Unbalanced Grid Voltage. IEEE Trans. Energy Convers. 2010, 25, 356-368. [CrossRef]

74. Wu, F.; Zhang, X.-P.; Ju, P.; Sterling, M.J.H. Decentralized Nonlinear Control of Wind Turbine with Doubly Fed Induction Generator. IEEE Trans. Power Syst. 2008, 23, 613-621. [CrossRef]

75. Qin, B.; Zhang, X.; Ma, J.; Deng, S.; Mei, S.; Hill, D.J. Input-to-State Stability Based Control of Doubly Fed Wind Generator. IEEE Trans. Power Syst. 2018, 33, 2949-2961. [CrossRef]

76. Qin, B.; Sun, H. State Dependent Riccati Equation Based Rotor-Side Converter Control for Doubly Fed Wind Generator. IEEE Access 2018, 6, 27853-27863. [CrossRef]

77. Lu, Y. Adaptive-Fuzzy Control Compensation Design for Direct Adaptive Fuzzy Control. IEEE Trans. Fuzzy Syst. 2018, 26, 3222-3231. [CrossRef]

78. Djeridane, M.E.; Mechgoug, R.; Ajgou, R.; Chemsa, A. Fuzzy Rotor Side Control of a DFIG-Based Wind Turbine. In Proceedings of the 2018 International Conference on Communications and Electrical Engineering (ICCEE), El Oued, Algeria, 17-18 December 2018; pp. 1-7. [CrossRef]

79. Raju, S.K.; Pillai, G.N. Design and Implementation of Type-2 Fuzzy Logic Controller for DFIG-Based Wind Energy Systems in Distribution Networks. IEEE Trans. Sustain. Energy 2016, 7, 345-353. [CrossRef]

80. Hu, J.; He, Y.; Xu, L.; Williams, B.W. Improved Control of DFIG Systems During Network Unbalance Using PI-R Current Regulators. IEEE Trans. Ind. Electron. 2009, 56, 439-451. [CrossRef]

81. Hu, J.; Xu, H.; He, Y. Coordinated Control of DFIG's RSC and GSC under Generalized Unbalanced and Distorted Grid Voltage Conditions. IEEE Trans. Ind. Electron. 2013, 60, 2808-2819. [CrossRef]

82. Ruiz-Cruz, R.; Sanchez, E.N.; Loukianov, A.G.; Ruz-Hernandez, J.A. Real-Time Neural Inverse Optimal Control for a Wind Generator. IEEE Trans. Sustain. Energy 2019, 10, 1172-1183. [CrossRef]

83. Rahimi, M.; Parniani, M. Coordinated Control Approaches for Low-Voltage Ride-Through Enhancement in Wind Turbines With Doubly Fed Induction Generators. IEEE Trans. Energy Convers. 2010, 25, 873-883. [CrossRef]

(C) 2020 by the authors. Licensee MDPI, Basel, Switzerland. This article is an open access article distributed under the terms and conditions of the Creative Commons Attribution (CC BY) license (http://creativecommons.org/licenses/by/4.0/). 